(1)

(C) Birkhäuser Verlag, Basel, 2008

\title{
Review
}

\section{Mesodermal fate decisions of a stem cell: the Wnt switch}

\author{
L. A. Davis ${ }^{\mathrm{a}}$ and N. I. zur Nieden ${ }^{\mathrm{b}, *}$ \\ ${ }^{a}$ Department of Surgery and Cambridge Institute for Medical Research, Addenbrooke's Hospital, \\ University of Cambridge, Hills Road, Cambridge CB2 2XY (United Kingdom) \\ ${ }^{\mathrm{b}}$ Fraunhofer Institute for Cell Therapy and Immunology, Deutscher Platz 5e, 04103 Leipzig (Germany), \\ Fax: + 49 341-355 3677 109, e-mail: nicole.zurnieden@izi.fraunhofer.de
}

Received 23 January 2008; received after revision 31 March 2008; accepted 04 April 2008

Online First 2 June 2008

\begin{abstract}
Stem cells are a powerful resource for cellbased transplantation therapies in osteodegenerative disorders, but before some kinds of stem cells can be applied clinically, several aspects of their expansion and differentiation need to be better controlled. Wnt molecules and members of the Wnt signaling cascade have been ascribed a role in both these processes in vitro as well as normal development in vivo. However some results are controversial. In this review we will present the hypothesis that both canonical and non-
\end{abstract}

canonical signaling are involved in mesenchymal cell fate regulation, such as adipogenesis, chondrogenesis and osteogenesis, and that in vitro it is a timely switch between the two that specifies the identity of the differentiating cell. We will specifically focus on the in vitro differentiation of adipocytes, chondrocytes and osteoblasts contrasting embryonic and mesenchymal stem cells as well as the role of Wnts in mesenchymal fate specification during embryogenesis.

Keywords. Stem cell, Wnt signaling, beta-catenin, adipogenesis, chondrogenesis, osteogenesis.

\section{Introduction}

Mature chondrocytes, osteoblasts and adipocytes are believed to arise from a common precursor cell, a stem cell. Stem cells have gained significant attention of late, since they hold great promise as a source for cell therapy in general, and specifically for therapies requiring adipocytes, chondrocytes and osteoblasts. For example, chondrocytes do not normally regenerate themselves after injury and medicinal treatment can only ameliorate joint disorders such as arthritis or joint injuries. Here, transplantation of cells that are able to reconstitute the tissue is often the only measure to cure a disease state. Moreover, cellular therapies with allogeneic stem cell-derived osteo-

* Corresponding author. blasts could become a treatment option for osteoporosis and osteogenesis imperfecta, where the endogenous cells could theoretically regenerate, but would carry a genetic defect. Stem cell-derived adipocytes are also becoming increasingly attractive to the cosmetic industry. Thus, stem cells can find application in regenerative medicine and/or reconstructive surgery.

To date, therapeutic applications of mesenchymal stem cell culture methods as a source for these three cell types have already been devised that withstand clinical quality controls. However, we are just beginning to understand the differentiation potential of other types of stem cells, such as embryonic stem cells. No matter what the final stem cell of choice for a certain therapeutic approach will be, it is imperative to comprehend how stem cells switch from proliferation to differentiation, a step that is critical for the normal 
development of every tissue, and how they switch between alternating differentiation paths. However, how the cell exits the cell cycle and decides between alternate differentiation pathways is not completely understood.

This review collates and examines recent insights into regulatory decisions of stem cells with regard to the adipogenic, osteogenic and chondrogenic program. First, it descriptively compares embryonic and mesenchymal stem cells and illustrates their advantages and caveats with respect to cell therapies and tissue engineering. In addition, it will introduce known transcription factors and other molecules thought to be involved in the development of these above mentioned cell types through an either direct or indirect interaction with the Wnt pathway, which plays an important role in embryo development in vivo and has been implicated into regulation of self-renewal and lineage diversification of stem cells in vitro.

\section{Sources of stem cells with mesenchymal lineage potential}

Stem cells can be derived from various sources and tissues. They can be sub-divided into two major groups: embryonic and adult stem cells. Both exhibit advantageous and disadvantageous characteristics for their use in tissue engineering and differ in origin, potency and therapeutic potential. Embryonic stem cells (ESCs) represent a population of cells that, once isolated, can be maintained in permanent culture for over fourteen months [1] and have thus been described as having an unlimited self-renewing capacity. However, discussions and controversies governing ethical issues surround their use in clinical applications. While the ethically uncontroversial adult stem cells can be harvested from most adult tissues, one of the limitations of these cells for their use in the clinic is their compromised proliferative potential. Adult stem cells, when isolated from younger donors, can only proliferate 24-40 population doublings in vitro before undergoing growth arrest. Those taken from older donors exhibit even earlier replicative senescence due to the absence of telomerase activity [2,3] and therefore the amount of stem cells that can be cultured sometimes simply limits their clinical usage especially for the repair of larger defects.

\section{Embryonic stem cells}

ESCs are derived from the inner cell mass of an embryo at the blastocyst stage of development. These cells are pluripotent and exhibit an extensive multiplication potential. Murine ESCs were first isolated over twenty-five years ago $[4,5]$. As many of the genes are similar between murine and human ESCs [6], the mouse model has become an important model system for studying cell replacement therapy [reviewed in 7] as well as the mechanisms for maintaining stem cell renewal, early commitment and epigenetic phenomena [8]. One of the first requirements to understanding the mechanism of differentiation is to understand how the cell maintains pluripotency. Once pluripotency can be maintained in culture, we can start researching the changes the cell must go through in order to become another more specified cell type.

A mouse ESC is maintained in its pluripotent state with the addition of Leukemia Inhibitory Factor (LIF) [9] or when cultured on feeder layers [8]. LIF is a member of the interleukin (IL)-6 cytokine family and binds to the low affinity LIF receptor (LIFR), which is expressed in the inner cell mass of mouse embryos [10]. This binding activates a downstream cascade by which transcription of pluripotency genes in the nucleus is ultimately activated [reviewed in 11]. Whereas the common believe is that pluripotency is actively switched on through addition of LIF, novel insights are currently shifting this paradigm. In fact, spontaneous differentiation of ESCs, in which pathways such as ERK1/2 are instrumental, must be indirectly blocked to maintain pluripotency [12]. Therefore the correct terminology for factors such as LIF should be differentiation inhibitor rather than pluripotency factor.

The first human ESCs were derived just before the turn of the century [13] opening up alternative possibilities for stem cell therapy. However, the use of ESCs as a tool in therapy for disease requires an understanding of the differences between mouse and human ESCs. There are some significant differences between mouse and human ESCs with regard to expression of markers and responsiveness to intrinsic signals, such as LIF. LIF is not sufficient to maintain pluripotency in human ESCs. Thus a variety of other signaling molecules have been implicated in selfrenewal. Basic Fibroblast Growth Factor (bFGF) in combination with noggin, bone morphogenic protein (BMP) 4, activin A and Wnt3a [14-17] have been described as supporting the ex vivo expansion of undifferentiated human ESCs. More differences between the species lie particularly in morphology, immunophenotype, and growth properties. For example, mouse ESCs grow in three-dimensional attached clusters, and have the appearance of a fried egg, whereas human ESCs grow in flat colonies that have distinct edges [reviewed in 18]. A set of alleged "stemness" genes, such as Oct-4, nanog and Sox-2, together with alkaline phosphatase and rex-1, serve as markers for pluripotency [19-22]. The Oct-4/Sox-2/ nanog triad in particular, share a substantial number 
of target genes [23, 24]. On a more global level, pluripotency seems to be controlled by polycomb complexes that repress transcription of particular chromosomal regions through epigenetic modification of the chromatin structure [25]. More recently, a special type of cell with pluripotent characteristics has been described, which had been artificially obtained by in vitro reprogramming of fibroblasts ectopically expressing a set of the four transcription factors Oct-4, Sox-2, c-myc and KLF4. In these so-called induced pluripotent (iPS) cells the DNA methylation status and chromatin state are similar to those of ESCs and these cells can contribute to the germ-line upon blastocyst injection [26, 27]. Although not ethically controversial, unlike the true ESC, iPS cells share some of the same concerns. As such, further research is due to find out how teratoma formation upon transplantation of non-fully differentiated cells can be prevented.

\section{Adult stem cells}

In contrast to ESCs, adult stem cells are set aside during embryonic development. In the adult body, they reside in almost every tissue and are thus also termed somatic stem cells. Capable of multi-lineage or uni-lineage differentiation only, they resemble a stem cell with a more restricted potential. Hence, compared to ESCs, somatic stem cells are one or multiple steps ahead in the differentiation process. A bone marrow derived but non-hematopoetic stem cell population commonly known as the mesenchymal stem cell (MSC) comprises a population of multipotential progenitors, which can give rise to multiple cell lineages including osteoblasts, adipocytes, chondrocytes and myoblasts [28-30]. Most MSCs differentiate relatively spontaneously into these lineages with minimal growth factor supplementation of the culture medium. Neuronal differentiation can also be achieved, but only with the addition of a complex cocktail of specialized growth factors [31, 32]. In contrast, MSCs can spontaneously express neural markers in vitro as can the pluripotent stem cell markers Oct-4 and rex-1 [33]. Due to these controversial data it therefore remains unclear whether neural differentiation of MSCs occurs via a process called transdifferentiation.

Although the most common source for MSCs is bone marrow, cells with similar characteristics have also been isolated from umbilical cord blood, fat aspirants, connective tissue, skin and placenta [32, 34-38]. MSCs can be distinguished by their fibroblast-like morphology and their characteristic of adhering to plastic surfaces [39], but molecular or cell surface markers are poorly defined. Therefore, the molecular identification of MSCs remains difficult. Some surface markers have been associated with MSCs recently, but have not been agreed on. The most widely used MSC markers are CD90, CD73 and CD105 [40]. Stro1, glycophorin A, D7-fib and low-affinity nerve growth factor receptor p75, also denoted CD271, and controversially CD 45 have also shown some success in the immuno-characterization of these cells [41-46]. Surface markers for ESCs on the other hand are well established, with SSEA-1 and alkaline phosphatase specific for mouse ESCs [47] and TRA-181, TRA-160 and SSEA3/4 for human ESCs [48], with novel molecular markers being added to the stemness palette with increasing frequency.

\section{Control of initial differentiation events through Wnts}

As discussed above there are a number of molecules that regulate the differentiation of adipocytes, osteoblasts and chondrocytes from stem or progenitor cells in vivo and in vitro. The Wnt signaling pathway is one of the pathways known to play a vital role in this process. The Wnt family of ligands consists of a number of highly evolutionarily-conserved secreted glycoproteins involved in many developmental processes such as cell differentiation, polarity, cell migration, cell proliferation and regeneration [49-51]. Wnts are thus essential for normal embryogenesis, but also actively participate in the regeneration of adult tissues, such as colon, skin, hair follicles and bone by controlling tissue specific adult stem cell function [52, 53]. Hence, it is not surprising that genes encoding Wnt pathway components are genetically and epigenetically altered in human cancer and disease [54].

The details of the Wnt signaling cascade have been extensively covered elsewhere [55] and shall only briefly be summarized here. The vertebrate Wnts have been historically divided into two functional groups; those that induce secondary axis formation in Xenopus embryos and those that do not induce an axis. The axis-inducing Wnts attach to the membrane bound receptor Frizzled (Fzd) initiating a directed signaling cascade that leads to the accumulation of $\beta$ catenin (CatnB) [56] and was later named the canonical pathway (Fig. 1). In addition to the Fzd receptor, classical canonical Wnt molecules bind to a coreceptor called low-density lipoprotein related protein 5/6 (LRP5/6) [57, 58].

In the absence of Wnt signal, a multiprotein complex involving axin, casein kinase 1 , glycogen synthase kinase 3 beta (GSK-3 $\beta$ ), adenomatous polyposis coli (APC) and Dishevelled (Dsh) mediate CatnB degradation (Fig. 2). APC and axin are two scaffold proteins which enable GSK-3 $\beta$ to bind and phosphorylate 


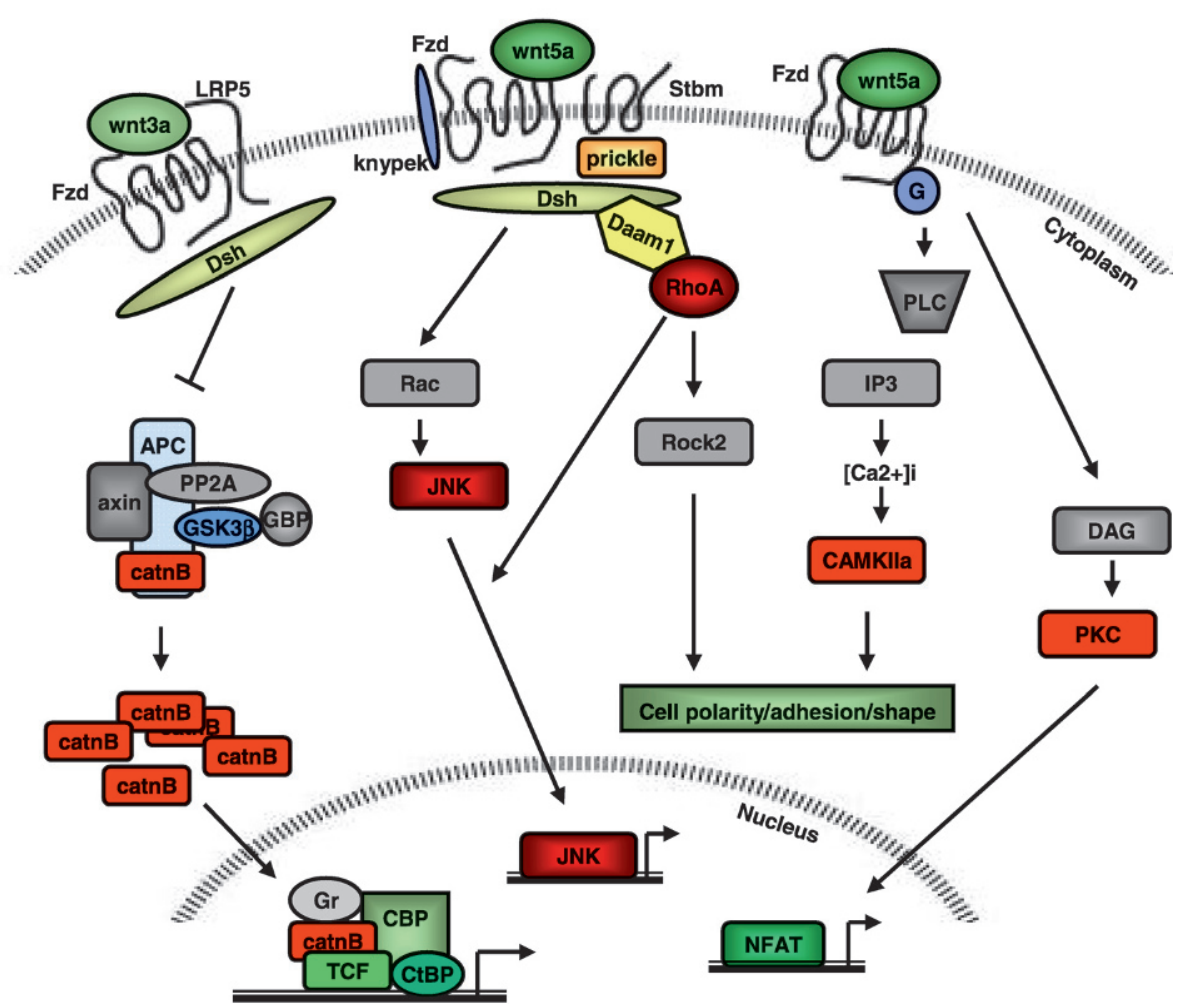

Figure 1. Canonical and noncanonical Wnt signaling pathways. There are at least three different intracellular Wnt signaling transduction pathways. These pathways are the Wnt/ CatnB pathway (canonical pathway), the $\mathrm{Wnt} / \mathrm{Ca}^{2+}$ pathway and the Wnt/planar cell polarity pathway. Both the $\mathrm{Wnt} / \mathrm{Ca}^{2+}$ pathway and the Wnt/planar cell polarity pathway are combined as the non-canonical pathway, which involve the downstream members calmodulin kinase II (Cam$\mathrm{KII}$ ), protein kinase $\mathrm{C}$ (PKC) and c-jun kinase (JNK). See text for more details.
CatnB. This phosphorylation creates binding sites for $\beta$-TrCP, an F-box protein in the E3 ubiquitin ligase complex, to attach and tag CatnB for proteasomemediated degradation $[59,60]$.

The intracellular tail of Fzds contains the motif KTxxxW which will recruit phosphorylated Dsh to the membrane when a Wnt ligand binds [61]. Dsh is a modular cytoplasmic protein that, once activated, suppresses the phosphorylation activity of GSK $3 \beta$ by interacting with proteins of the degradation complex $[62,63]$.

CatnB can also be regulated in a non-GSK3 $\beta$ manner by recruitment of axin to the membrane by LRP5/6, which causes axin degradation. As a consequence, CatnB is no longer bound to the APC-axin-GSK3 $\beta$ complex.

In both cases, degradation of CatnB is prevented and accumulates in the nucleus, where it binds to the transcription factors lymphoid enhancer factor (LEF) and/or T-cell factor (TCF) triggering downstream gene transcription (including that of c-myc and Cyclin $\mathrm{D}_{1}$ ) by converting LEF/TCF from transcriptional repressor to activator [reviewed in 64; 65-67]. LEF$1 / \mathrm{TCF}$ proteins bind to the CatnB central armadillo repeats in a region that largely overlaps with the binding sites for APC [68]. Because of the competition between APC and LEF for overlapping regions of the CatnB molecule, CatnB cannot interact with APC when bound to LEF and vice versa, a mechanism whereby transcriptional activation of its targets can be controlled.

The non-axis producing, non-canonical Wnts, in turn, do not signal through CatnB and in some cases inhibit nuclear CatnB activity [69]. Similar to the canonical pathway, the non-canonical pathways also require Fzd as the receptor. However, they do not require LRP5/6, which typically acts as a co-receptor in canonical signaling, but instead a proteoglycan protein called Knypek [70]. Downstream, Dsh is also involved in further transducing the non-canonical signal. However, it appears that different Dsh domains are required in the canonical versus the non-canonical pathway [71, 72]. For instance, recruitment of Dsh to the cell membrane occurs through its DEP domain only in the non-canonical pathway $[71,73]$.

This non-canonical pathway is less characterized and the proteins involved, as well as their interactions in the cascade, are controversial. To date, the noncanonical pathway has been split into 3 sub-pathways, 2 of which release calcium ions into the cytoplasm. These 2 pathways are involved in cell adhesion and cell shape. The third pathway is involved in cell polarity (Fig. 1).

To complicate things, the canonical and non-canonical pathways are not distinct as some Wnts can signal through both pathways [74] and some downstream 


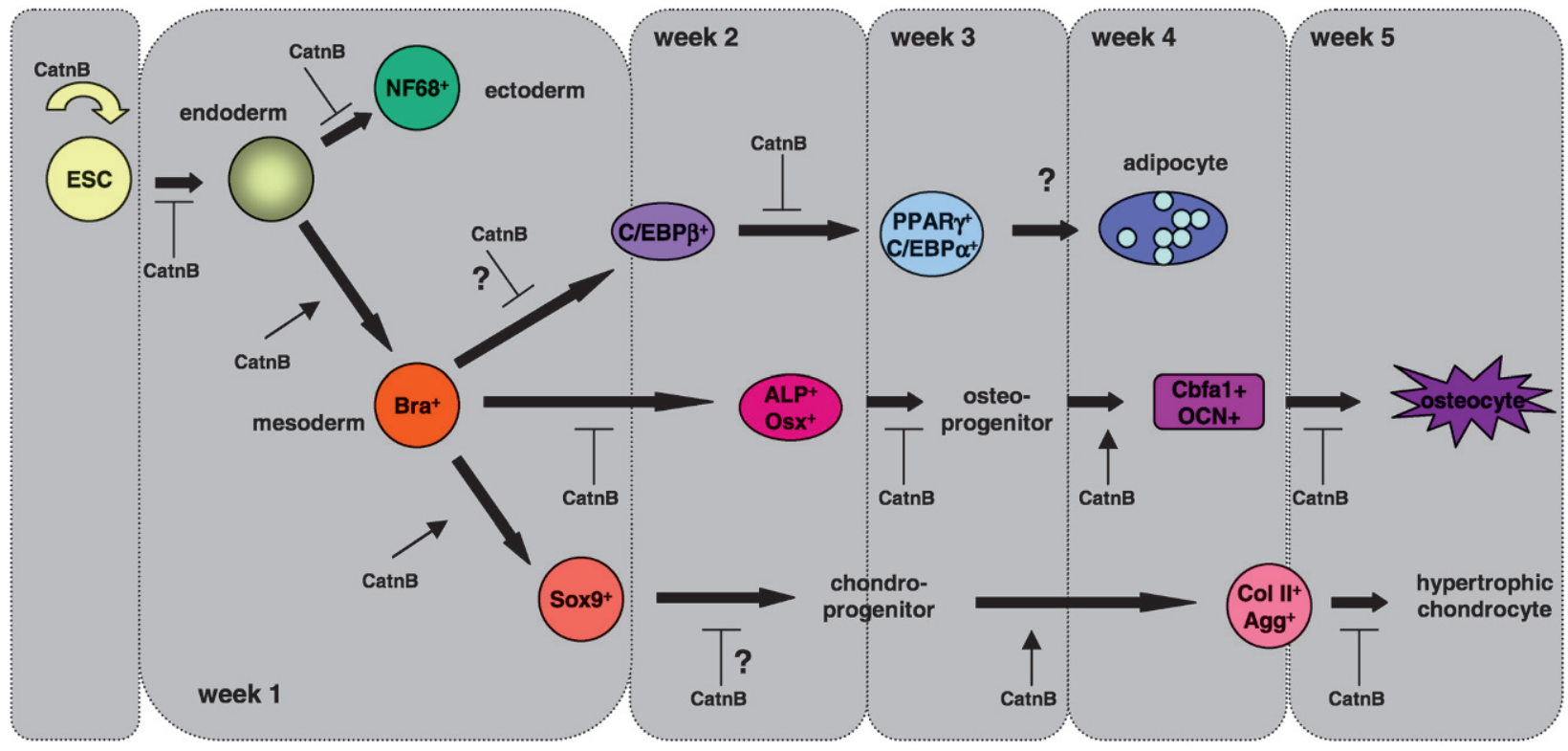

Figure 2. Regulation of ESC differentiation through CatnB. Activation or blockage of nuclear CatnB activity controls lineage decisions. The duration of the specific signal plays a role in the transcriptional activation of lineage-specific transcription factors. See text for details.

targets are involved in both, such as Dishevelled (Dsh) (Fig. 1) [reviewed in 75]. The combination of pathway members seems to depend on the cellular context. In stem cells, Wnt/CatnB signaling regulates cellular function at the level of maintaining 'stemness'. However, both the canonical (nuclear CatnB activity) as well as the non-canonical cascade (blockage of nuclear CatnB activity) also control differentiation (Fig. 2).

Here, the activity level of CatnB in the nucleus seems to play an important role. In ESCs, overexpression of the canonical Wnt1 or stabilized CatnB results in the inhibition of neural differentiation and in the activation of cell cycle genes such as c-myc and cyclins supporting self-renewal [76, 77]. Additionally, GSK$3 \beta$ can phosphorylate $\mathrm{p} 53$, which in turn suppresses nanog expression thus supporting differentiation [78]. Blockage of GSK-3 $\beta$ would therefore assist in maintenance of pluripotency, possibly through regulation of p53 and nanog. These data have been verified by Sato et al. [79], who artificially inhibited GSK-3 $\beta$ with BIO perpetuating Oct-4 expression. Addition of Wnt3a supported pluripotency in human and mouse ESCs even without a feeder layer or LIF, respectively, and sustained the characteristic phenotype of the respective cultures. Independent from Wnt ligand binding, the natural upstream negative regulator of GSK-3 $\beta$ in ESCs was recently identified to be PI3K and Akt [80]. Finally, mutations in APC that are associated with increased intracellular doses of CatnB interfere with ESC differentiation into the three germ layers [81].
The first switch in Wnt signaling occurs when the ESC decides to differentiate. Whereas CatnB uses the cofactor CREB-binding protein (CBP) to regulate the expression of pluripotency and cell cycle associated genes to maintain stemness, upon differentiation $\mathrm{CatnB} / \mathrm{p} 300$ is activating a different set of target genes, thereby initiating differentiation [82]. Here, c-myc is one of these downstream genes and since it is targeting cell cycle regulators it is responsible for continuous proliferation of the differentiating cells. In addition, the expression of the noncanonical Wnt5a is abruptly increased upon differentiation (Fig. 3).

Aside from controlling self-renewal and early differentiation, the Wnt signaling pathway thereafter specifically regulates the lineage-specification of mesenchymal precursor cells into adipocytes, osteoblasts and chondrocytes [83-85]. However, not only chemical cues, but also physical activation such as cell density and cell shape appear to play a role in lineage commitment. Mesenchymal condensations are characterized by increased cell density and cell-cell adhesion. Lower cell densities seem to support osteoblast differentiation of MSCs whereas higher cell densities cause the cells to condense, forcing cells to become adipocytes [86]. In this context, cell shape seems to be regulated by RhoA, a downstream target of the non-canonical Wnt pathway. Moreover, Ncadherin, a calcium dependent protein involved in cell-cell adhesion, directly interacts with CatnB at the plasma membrane [reviewed in 87]. This interaction occurs specifically at the time of mesenchymal con- 


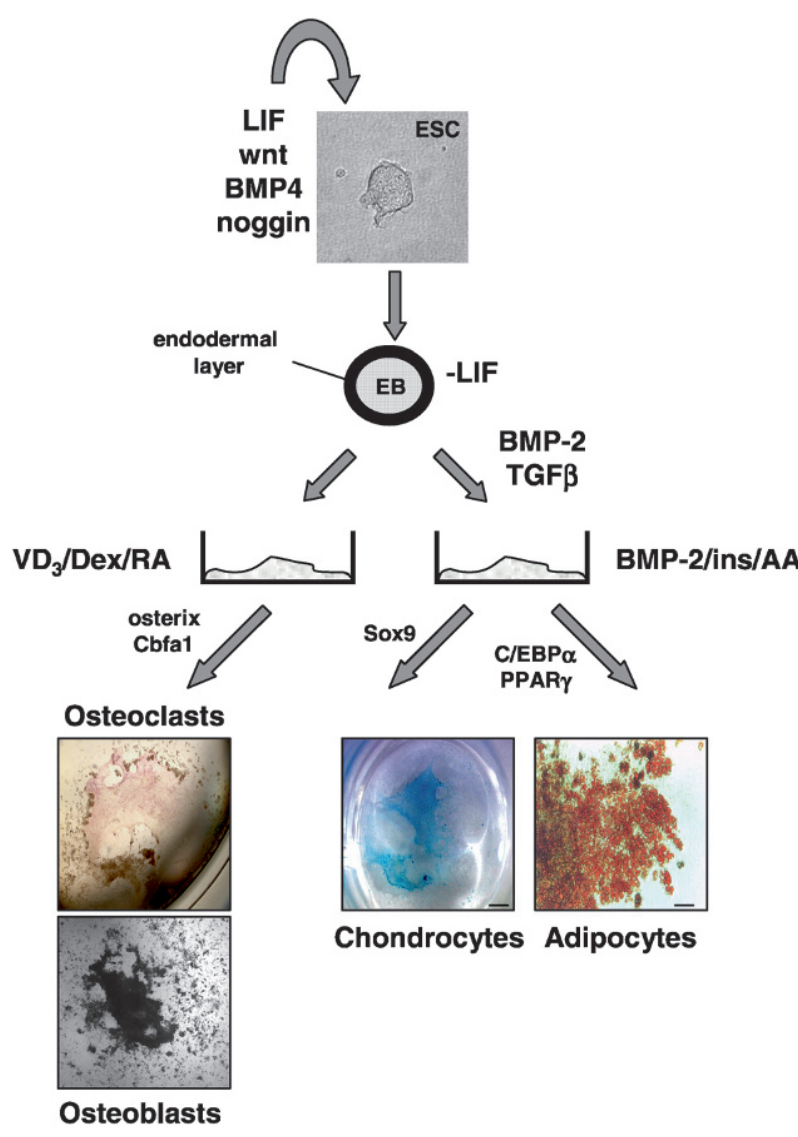

Figure 3. Exogenous factors control ESC fate. Whereas LIF, Wnt signaling, BMP-4 and noggin contribute to the undifferentiated phenotype and self-renewal of ESCs, withdrawal of LIF induces embryoid body (EB) formation and differentiation. Within two to three days, a single cell layer of endodermal origin forms as an outer sheet of the EB. Afterwards, various factors induce lineage specification through up-regulating lineage-specific transcription patterns thus pushing the cells to a mature fate. Ins = Insulin, AA = ascorbic acid, $\mathrm{Dex}=$ dexamethasone, $\mathrm{RA}=$ retinoic acid, $\mathrm{VD}_{3}=$ vitamin $\mathrm{D}_{3}$.

densations before differentiation begins [87]. During cellular differentiation into chondrocytes, N-cadherin expression decreases along with CatnB expression and with increased Collagen type IIa expression. Therefore, the regulation of CatnB and $\mathrm{N}$-cadherin in cell-cell adhesion is necessary for mesenchymal condensations but not the subsequent differentiation of chondrocytes.

Due to their pluripotent differentiation ability, ESCs are ultimately capable of differentiating into mesodermal lineages (Fig. 4) - such as adipocytes, osteoblasts and chondrocytes [88-93].

Differentiation is commonly induced by withdrawal of differentiation inhibitors and physical aggregation of the cells into embryoid bodies. Mesodermal and endodermal cells appear with continued differentiation [reviewed in 94], but the progression of differentiation varies with the type of aggregation system $\begin{array}{lllllllllll}0 & 1 & 2 & 3 & 4 & 5 & 6 & 7 & 8 & 9 & 10\end{array}$

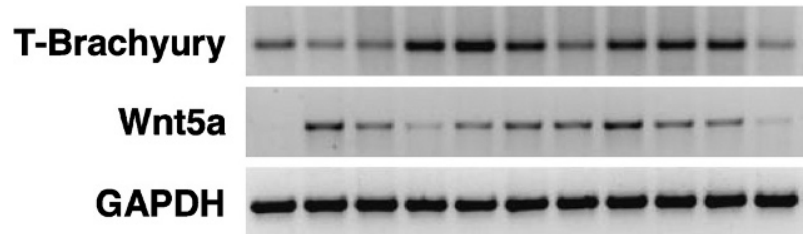

Figure 4. Mesodermal specification in ESCs. During differentiation of murine ESCs, the mesodermal marker T-Brachyury is expressed in two waves from $\mathrm{d} 3-5$ and again from $\mathrm{d} 7-9$. In contrast, the non-canonical Wnt5a is expressed with beginning differentiation and its expression level decreases before the onset of the first Brachyury wave. Later, Wnt5a expression is increased around differentiation day $6-9$ induced by vitamin $D_{3}$.

utilized. Brachyury (T-Bra), a transcription factor expressed in the primitive streak in vivo, is detectable on day three of differentiation. Whereas a prolonged T-Bra expression until day seven has been described elsewhere [94], we and others rather find two expression waves [95]. Studies from the Keller laboratory suggest that the first wave of T-Bra expression marks a hemangioblast population and that sorted T$\mathrm{Bra}^{+}$cells from the second wave give rise to cardiomyocytes and represent a mesodermal population [summarized in 96]. As adipocytes, osteoblasts and chondrocytes form out of the mesoderm these events might as well mark the first days of adipo-, osteo- and chondrogenesis in vitro.

\section{Molecules that characterize adipogenesis, chondrogenesis and osteogenesis}

Lineage relationships and transcription factors. After the cell has started the differentiation program and has been pushed toward the adipo-, chondro- or osteogenic cell fate there are a number of genes that are up-regulated at a specific time during differentiation. These genes will define the cell as a particular cell type when observed through gene expression studies. This section will introduce the molecules that characterize the cell and are used effectively as signposts to aid the researcher in distinguishing what stage a cell is at during differentiation. The stages of differentiation these molecules are expressed at provide a framework for researchers to study the Wnt pathway and its regulation of these differentiation programs, which is outlined later in this review.

The relationship between each of these three cell types can be outlined in a summary of the major transcription factors that may be necessary for their specification to their respective lineages. These transcription factors include CCAAT/Enhancer binding protein $(\mathrm{C} / \mathrm{EBP})$ alpha and peroxisome proliferatoractivated receptor (PPAR) gamma for adipocytes [97, 
98], core binding factor alpha 1 (Cbfa1/Runx2) and osterix for osteoblasts $[99,100]$ and Sox 9 for chondrocytes [101]. These lineage-specific transcription factors, although mostly regulating their own transcription through a positive feedback mechanism (i.e. Runx2 and $\mathrm{C} / \mathrm{EBP} \alpha$ ), can also inhibit differentiation of other lineages by suppressing gene expression. As such, Runx2 null chondrocytes revert into adipocytes in vitro [102]. PPAR $\gamma$ on the other hand inhibits Runx2 expression and thus terminal osteoblast differentiation [103].

Once differentiation has been initiated, further lineage decisions seem to be largely regulated by members of the nuclear hormone receptor family including PPAR, retinoic acid and retinoid X receptors (RAR/RXR) and vitamin $\mathrm{D}_{3}$ receptors (VDR), which are indeed commonly used to trigger differentiation in vitro $[92,93,104]$. All three receptors are activated by ligands and translocated to the nucleus. Through the binding to hormone response elements within the promoter of target genes, these receptors will then control gene expression [reviewed in 105]. During differentiation of ESCs towards adipocytes PPAR $\gamma$ is activated [104], supplementation with retinoic acid (RA) leads to enhanced chondrogenesis [93] and vitamin $\mathrm{D}_{3}\left(\mathrm{VD}_{3}\right)$ activates the osteogenic program [92, 104]. Interestingly, both PPAR and VDR heterodimerize with the RXR receptor [105, 106] and transcriptional activation by both are controlled through interactions with co-activators and co-repressors [107]. Signaling pathways known to be involved in the nuclear receptor family and consequent interactions are the mitogen-activated protein kinase (MAPK), phosphinositide 3 kinase (PI3K)/Akt and Wnt pathways [reviewed in 105]. Thus, all three nuclear receptors mediate their effects through ligand binding, gene activation and post translational events.

Adipogenesis. Adipogenesis, like the development of other lineages, is a tightly controlled, well-orchestrated sequence of events regulated by positive and negative stimuli [108]. Differentiation of the multipotent stem cell line $\mathrm{C} 3 \mathrm{H} 10 \mathrm{~T} 1 / 2$ and preadipocyte cell lines, such as 3T3-L1 and 3T3-F442A cells into adipocytes can be divided into four phases: I) Preconfluent proliferation II) confluence/growth arrest III) hormonal induction/ clonal expansion IV) permanent growth arrest/ terminal differentiation. The later part is controlled by specific transcription factors involving $\mathrm{C} / \mathrm{EBP}$ proteins and PPAR $\gamma$, which act in a time-regulated fashion.

Specifically, adipogenesis is controlled by the C/EBP family members $\mathrm{C} / \mathrm{EBP} \alpha, \beta, \delta$ and $\mathrm{CHOP}-10$ [reviewed in 109]. Although $\mathrm{C} / \mathrm{EBP} \beta$ is expressed immediately after induction of differentiation, only when the cells enter the mitotic clonal expansion phase (phase III) the DNA binding capacity of $\mathrm{C} /$ EBP $\beta$ is activated [110, 111]. As a regulator of terminal adipogenesis entering phase IV, C/EBP $\beta$ subsequently activates transcription of $\mathrm{C} / \mathrm{EBP} \alpha$ through binding to a $\mathrm{C} / \mathrm{EBP}$ regulatory element in the $\mathrm{C} / \mathrm{EBP} \alpha$ promoter [112].

The second adipocyte-specific transcription factor is $\operatorname{PPAR} \gamma$. Out of the three known PPAR $\gamma$ isoforms expressed in adipocytes, only PPAR $\gamma_{2}$ seems to be the adipocyte-differentiation regulating splice variant [113]. Although first discovered as an orphan receptor, it is now certain that 15 -deoxy-delta $(12,14)$ prostaglandin $\mathrm{J} 2$ functions as the endogenous ligand of PPAR $\gamma[114,115]$. Externally added thiazolidinedione (TZD) compounds may also activate this receptor providing novel tools to steer differentiation in vitro.

Aside from studies on adipocyte precursor cells, ESCs provide another powerful model to further understand the early stages of adipogenesis. Ten years ago, the first report of ESCs being capable of adipogenic differentiation was published by Dani and coworkers for murine cells [88]. In their paper, they described that adipocytic colonies arose when ESCs were exposed to all-trans retinoic acid (RA) during days $2-5$ of differentiation followed by stimulation with the adipogenic hormones insulin and triiodothyronine $\left(T_{3}\right)$. In contrast, ESCs were not responsive to RA after day 5 and treatment with neither rosiglitazone, a PPAR agonist of the TZD family, nor fatty acid 2bromopalmitate induced adipogenesis at this stage of differentiation. Captivatingly, the restrictiveness of the permissive period for RA induction to differentiation days 2 to 5 coincides with the expression of Brachyury, the gene expressed during primitive streak formation in vivo. Underlying the hypothesis that adipocytes form out of the mesoderm, this strongly suggests that RA would act during a time of in vitro differentiation which corresponds to primitive streak formation in vivo.

However, based on our own data, which suggests that Brachyury expression is accompanied by increased activity of the CatnB/TCF axis in the nucleus [N. I. zur Nieden, unpublished data], and the fact that RA treatment, however, will inhibit this activation [116], it is questionable that RA treatment during early ESC differentiation truly increases the output of mesodermal cells. Indeed, Kawaguchi et al. [117] have reported that treatment with RA on differentiation days 2 to 5 markedly decreased Brachyury expression in mESCs. Moreover, a recent study by Billon et al. [118] rather suggests that adipocytes in ESC cultures are of neural crest origin, which seems to be a likely hypothesis as 


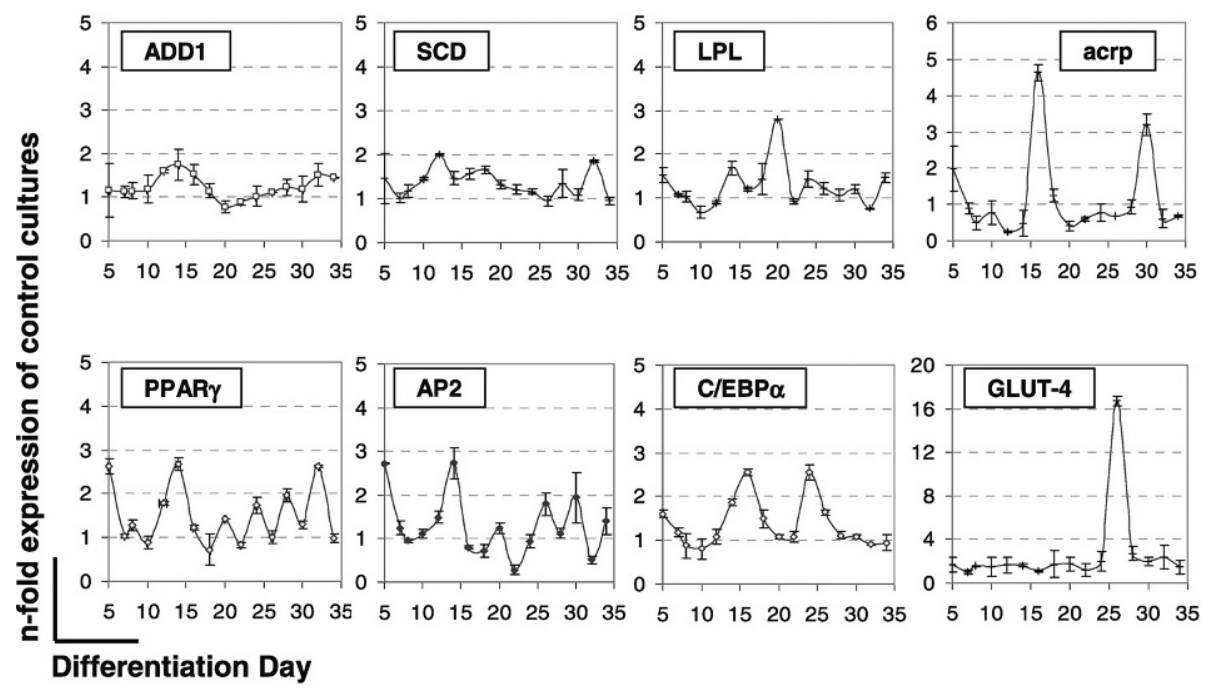

Figure 5. Expression profiling of ESC-derived adipocytes. The expression level of adipocyte-specific transcription factors and markers of the mature adipocyte phenotype were determined by quantitative PCR. Expression of genes of interest was normalized to GAPDH, a housekeeper in ESC differentiation. Expression in adipocyte cultures is represented as fold-induction in respect to spontaneously differentiating non-induced controls.

RA treatment may also enhance the yield of neural cells in ESCs.

Furthermore, our group has previously shown that BMP-2 also can induce the adipogenic program in murine ESCs depending on specific co-factors. Together with insulin, BMP-2 can activate adipocytespecific expression patterns, including transcription of PPAR $\gamma$ and $\mathrm{C} / \mathrm{EBP} \alpha$ (Fig. 5), but also genes expressed in more mature functional adipocytes, such as GLUT4 [104].

Adipocytes can also be derived from human ESCs and MSCs with rosiglitazone [119, 120]. Specifically, in ESCs spontaneous embryoid body formation was induced with no specific adipogenic factors and subsequently, rosiglitazone was added on day six of differentiation. The altered timing of induction factor usage is simply due to the fact that progression of differentiation is generally slower in human ESCs as compared to mouse ESCs. With longer population doubling times in human ESCs, Brachyury is expressed on day 7 and not on day 3 as in murine cells (Fig. 4). Two days into the addition of rosiglitazone, serum concentrations were increased from $10 \%$ to $20 \%$. The human ESC-derived adipocytes that subsequently formed were shown to express PPAR $\gamma_{2}$ at very low levels and the three adipocyte markers ADD1, adiponectin and aP2 only after 20 days in differentiation medium. Again, timing of differentiation is not congruent with murine ESC adipogenesis, as murine ESCs express most adipogenic markers after two weeks of in vitro differentiation (Fig. 5). However, the succession of certain differentiation steps seems to be similar in both species. The fact that progenitor differentiation was induced 'spontaneously' by some serum component in human ESCs supports the notion that rosiglitazone treatment acted on the progenitors that had formed during the inductive phase, a process that is also seen in murine ESC adipogenesis. It remains unclear whether these progenitors are mesodermal or rather neural crest progenitors. Based on the presented data however, it can be hypothesized that both murine ESCs as well as human ESCs closely follow the stepwise adipogenic differentiation program described for pre-adipose cell lines above: a permissive period for a) the commitment of progenitors to adipocyte-progenitors and $b$ ) for terminal differentiation requiring adipogenic hormones.

\section{Chondrogenesis}

As we have summarized for adipogenesis, activation of certain signaling pathways and their downstream targets such as lineage-specific transcription factors seem to exclusively regulate the progression into mesodermal lineages. Differentiation of ESCs into the chondrogenic lineage cannot only be enhanced by transcriptional activation of target genes by external soluble factors, but also by co-culture with limb bud progenitor cells [121]. Co-culture systems have the advantage of allowing direct cell-cell-contact potentially leading then to the activation of signaling pathways that are dependent on the intercellular coupling of two cell types. Moreover, secreted autocrine and paracrine molecules can effect the respective other cell more readily. A major shortcoming of this technique, however, is the difficulty of separating the cells from one another for subsequent transplantations or adequate in vitro analyses.

In addition to their role in adipogenesis reviewed above, BMPs as soluble factors can also initiate the chondrogenic program. Short term BMP-2 expression is sufficient to induce the chondrogenic program in MSCs [122]. During chondrogenic differentiation, the MSCs also constantly express TGF $\beta 1, \beta 2, \beta 3$ and $\beta 4$ 
[123]. Furthermore, it has been suggested through purification of a flk ${ }^{+}$PDGFR $\alpha$ progenitor population differentiated from ESCs and the subsequent addition of TGF $\beta_{3}$ that chondrogenesis in ESCs follows both a TGF $\beta$-dependent and a TGF $\beta$-independent pathway [124]. The addition of BMP-4 at later stages of the culture resulted in the formation of hyaline cartilage, but early supplementation was rather detrimental. The described study thus implies that chondrogenesis in ESCs follows two critical steps first requiring TGF $\beta$ then followed by BMP-4. However, this is after mesoderm has been committed and the flk ${ }^{+}$PDGFR $\alpha$ mesodermal progenitors were isolated for further culture. Kramer et al. [89] on the other hand have seen a positive effect of BMP-4 as well as BMP-2 on chondrogenesis in ESCs by adding these factors in the early phase immediately after a mesendodermal state has been reached. Our group has shown previously that continuous BMP-2 supplementation during all phases resulted in an over 37-fold increase in collagen type IIb expression compared to early supplementation alone [104].

The described studies give credence to the fact that induction of chondrogenesis by BMP- 2 commences on day 3 of differentiation, illustrating that BMP-2 can act to enhance the hemangioblast population. However, the enforced supplementation of BMP-2 until chondrocytes are mature (differentiation day 32) seems to support the notion that BMP-2 also regulates the lineage specification programs at later time points as described in Nakayama et al. [124]. We will not rule out that BMP supplementation could be halted in midphase chondrogenesis and re-initiated in the late phase of development to further augment chondrogenesis. Similar to the division of adipogenesis into specific stages, it seems thus appropriate to stage chondrogenic differentiation into four phases: I) differentiation initiation, II) mesoderm formation (BMP-dependent), III) a TGF $\beta$ responsive period and IV) a second BMP conductive phase.

\section{Osteogenesis}

Mineralization of ESCs and MSCs has been shown to be triggered by $\beta$-glycerophosphate and ascorbic acid [90-92, 125]. In vitro differentiation into osteoblasts from both stem cell sources closely resembles in vivo bone formation, also travelling through different phases just like adipogenesis and chondrogenesis. In ESC osteogenesis, at least four phases can be distinguished: I) a proliferation stage is followed by II) mesenchymal commitment, III) matrix deposition and finally IV) matrix mineralization. Each of these stages is characterized by the expression of lineage-specific genes. In ESCs, according to current protocols, phase I and II occur spontaneously upon removal of LIF and differentiation initiation in hanging drops [92]. Osteogenesis is then induced in phase III with the addition of $\mathrm{VD}_{3}$ [92] or dexamethasone [91, 126]. The following five days of phase III of osteoblast induction show a small increase in Runx2 accompanied by osteopontin and collagen type I expression [92]. However, the bone-specific isoform of alkaline phosphatase (ALP) known to up-regulate in early osteogenesis was found to peak in RNA expression and enzyme activity on differentiation day 15 [92]. This enzyme precedes the osteoblast phenotype and is thought to play a role in the initiation of mineralization. The expression of ALP was followed by osteopontin expression in murine ESC osteogenesis. The final week of osteogenesis in vitro is marked by an increase in Runx 2 followed by a second peak of ALP expression, and finally osteocalcin and bone sialoprotein expression, which mark the mature osteoblast phenotype [92].

Furthermore, overexpression of osterix, the second major osteoblast-specific transcription factor alongside Runx2, is sufficient to initiate osteogenesis in ESCs upregulating osteocalcin expression and translocating Runx2 into the nucleus, where it can activate transcription of osteoblast-specific target genes [127]. Osterix itself seems to regulate its own transcription through a positive feedback-loop as osterix overexpressing ESCs show enhanced osterix expression on day 7 of differentiation. Here, dexamethasone synergistically enhances osterix-induced osteogenesis when added in late osteogenic phase III. In our hands, osterix is endogenously expressed on day 6 of differentiation in the osteogenic induction phase, when mesodermal progenitors are in the transition phase towards committing an osteogenic precursor (data not shown). Thus, it appears that dexamethasone acts down-stream of osterix further committing the cells to an osteoblast fate. Ultimately, through the expression of certain genes the stage of osteoblast differentiation in vitro can be determined.

Whereas adipogenesis and chondrogenesis occur simultaneously in the same culture dish in ESCs, chondrogenesis and osteogenesis seem to be mutually exclusive. BMP-2 alone can not support mineralization of ESCs, but induces expression of osteocalcin and osteopontin [104]. Addition of BMP-2 together with $\mathrm{VD}_{3}$ augments the osteogenic response of the cells, but is unable to meet the levels that are attained by $\mathrm{VD}_{3}$ alone. However, chondrogenic cultures can convert to mineralized osteoblasts when $\mathrm{VD}_{3}$ is given on differentiation day 20, arguing in favor of an involvement of BMP-2 in endochondral bone formation. Likewise, BMP-2 has a supportive effect on osteoblast cultures in differentiation phase IV [116]. Aside from inducing osteogenesis, $\mathrm{VD}_{3}$ has been indicated to enhance osteoclast lineage development 
in ESCs [128]. Hence, both cell types characteristic for functional bone, the osteoblast and the osteoclast, can be found in $\mathrm{VD}_{3}$ induced ESCs (Fig. 3), rendering the $\mathrm{VD}_{3}$ model an important in vitro system that allows the study of cellular interactions that normally occur in bone tissue in vivo.

\section{How Wnt signaling controls cell fate}

Based on the expression pattern of the presented lineage markers adipo-, chondro- and osteogenesis can be staged according to the differentiation progression. Captivatingly, all three differentiation paths seem to be regulated in stages. In the following paragraphs, we will present evidence for the fact that each progression into the next differentiation stage is accompanied by a switch from non-canonical Wnt signaling to canonical Wnt signaling or vice versa.

The question arises how Wnts can exert diverse functions in stem cells. The activation of downstream targets is likely to be mediated by cell-type specific intrinsic properties and expressed co-activators as well as mechanical properties of the cellular environment; which is not only true for stem cell maintenance, but also differentiation. Whereas in undifferentiated ESCs, CatnB binds to LEF/TCF transcription factors leading to transcription of cell cycle regulatory genes, CatnB can also undergo direct binding to other coactivators such as Early B-cell Factor 2 (EBF2) regulating RANK-RANKL during osteoblast-dependent osteoclastogenesis [129]. Furthermore, binding of the CatnB/LEF-TCF-complex to Smads has been described in response to TGF $\beta$ and BMPs during development of the Speeman's organizer in Xenopus $[130,131]$. With regard to osteoblast differentiation, a functional binding site for LEF1 was found adjacent to the proximal Runx2-binding site in the osteocalcin promoter. In transcription assays, LEF1 repressed Runx2-induced activation of the mouse osteocalcin 2 promoter in several osteoblast lineage cell lines [132]. The interaction between the DNA-binding domains of Runx2 and LEF1, as a nuclear effector of the Wnt/ CatnB signaling pathway, was found crucial for LEF1mediated repression of Runx2 and essential for osteoblast proliferation and normal skeletal development. The internuclear presence of these co-factors in turn depends on the extracellular environment of the cell and induction of other signaling pathways (i.e. TGF $\beta$, BMPs) activated by extracellular stimuli. In conclusion, the output of Wnt signaling is highly determined by a combined activity of multiple factors.

\section{Adipogenesis}

Wnts that induce a signaling pathway through PPAR, specifically the non-canonical Wnt5a, regulate the growth, differentiation, apoptosis and insulin sensitivity of the differentiating adipocytes [133]. However, during early adipogenesis, a timely activationinactivation of the Wnt pathway is essential for the induction of PPAR $\delta$ and PPAR $\gamma[134,135]$. Canonical Wnt signaling is responsible for keeping pre-adipocytes in the 'undifferentiated state', promoting cell proliferation with the activation of cyclin D1 and cmyc while inhibiting PPAR. Cyclin D1 and c-myc inhibit by binding directly to PPAR and the C/EBP $\alpha$ transcription factor, respectively [136, 137]. Moreover, the expression of $\mathrm{C} / \mathrm{EBP} \alpha$ coincides with the phosphorylation of CatnB and subsequent degradation. Consequently, in order to facilitate differentiation, nuclear CatnB activity is down-regulated and non-canonical signaling is switched on [138]. This process is dependent on GSK-3 $\beta$, which phosphorylates CatnB, targeting it for degradation in the proteasome.

Simultaneous induction of PPAR $\gamma$ expression suggests that CatnB could block PPAR $\gamma$ expression and PPAR $\gamma$ in turn can direct CatnB for proteasomal degradation. Activation of canonical signaling through Wnt1, Wnt10b and a CatnB mutant that increases CatnB stability has been shown to inhibit 3T3-L1 adipocyte differentiation, a cell line commonly used as a model for white adipocyte differentiation, suggesting that Wnt10b mRNA, free CatnB and adipogenesis are inversely correlated [85, 139]. In particular, Wnt10a has been shown to exert an inhibitory function in the differentiation of white adipose tissue through down-regulation of the transcription factors $\mathrm{C} / \mathrm{EBP} \alpha$ and PPAR $\gamma$. The distinction between Wnt10a and 10b in white versus brown adipocytes suggests involvement of diverse Wnt family members in the regulation of the two types of adipose tissue. Wnt10b is expressed in preadipocytes, decreasing in differentiating adipocytes thereby inhibiting adipogenesis and promoting osteogenesis [140]. Furthermore, Wnt10b shifts cell fate towards the osteoblast phenotype by regulating the expression of Runx2, Dlx5 and osterix and down-regulating the expression of $\mathrm{C} / \mathrm{EBP} \alpha$ and PPAR $\gamma$. Similarly, Wnt3a overexpression inhibits PPAR $\gamma_{2}$ expression and adipocyte fatty acid binding protein in $\mathrm{C} 3 \mathrm{H} 10 \mathrm{~T} 1 / 2$ cells [141].

Another link between Wnt signaling and adipogenesis can be found in GSK-3 $\beta$, which in addition to phosphorylation of CatnB can also phosphorylate $\mathrm{C} /$ EBP $\alpha$. Here, insulin treatment dephosphorylates Thr222 and Thr226 residues of $\mathrm{C} / \mathrm{EBP} \alpha$ through inactivation of GSK-3 $\beta$ and leads to a decrease in $\mathrm{C} /$ 
EBP $\alpha$ mRNA and protein [142]. Treatment of 3T3-L1 adipocytes with the GSK-3 $\beta$ inhibitor, lithium chloride, thus blocks differentiation [143].

Further confirmation of involvement of non-canonical Wnt signaling in adipogenesis stems from the studies of Bandyopadhyay et al. [138] in ESCs, who have shown that insulin can activate PKC $\lambda$, a noncanonical Wnt downstream target, and thus stimulates glucose transport in undifferentiated ESCs. Both phenomena, the activation of PKC $\lambda$ as well as the glucose transport, are dependent on activation of proline-rich tyrosine protein kinase 2 (PYK2), the ERK pathway and phospholipase D (PLD), but are independent of PI3K [144]. In contrast, during differentiation of the ESCs to lipid filled adipocytes induced by insulin, dexamethasone and isobutylmethylxanthine, this dependency was completely reversed. Insulin effects on $\mathrm{PKC} \lambda$ and glucose transport were in that case dependent on PI3K, rather than PYK2/ ERK/PLD. These findings suggest that atypical PKCs are required for insulin-stimulated glucose transport regardless of the downstream signaling cascade.

The listed evidence suggests that progression of the adipogenic program might be controlled by fluctuations in nuclear CatnB activity achieved by switching from canonical to non-canonical Wnt signals. Moreover, increased expression of canonical Wnt pathway genes inversely correlates with the size of adipogenic cells suggesting a compensatory increase of energy partitioning or lipid accumulation to the existing adipocytes resulting from impairment in the generation of new adipocytes [145].

\section{Chondrogenesis}

The role of the Wnt pathway in chondrocyte differentiation also revolves around the location and expression of CatnB. Although the canonical pathway is involved in mesenchymal condensations, other proteins such as the chondrocyte specific transcription factor Sox 9 are also involved. In fact, CatnB and Sox 9 negatively regulate each other and it has been suggested that CatnB binds Sox9 at its transactivation domain thus effectively inhibiting its activity [146]. Similar to the switch between canonical and noncanonical signaling described for adipogenic differentiation events, CatnB expression levels are high in prechondrogenic mesenchyme decreasing while cells travel through differentiation to become mature chondrocytes [147] thus allowing for Sox9 expression to increase. Constitutively active CatnB inhibits chondrocyte differentiation by reducing collagen type II and Sox9 expression in cultured chicken chondrocytes [147] and proliferation in the growth plate in vivo [148]. Similarly, Wnt5a may promote chondrocyte differentiation in the distal limb bud by inhibiting canonical activity [149]. As such, Wnt5a $\mathrm{a}^{-{ }_{-}}$ embryos are characterized by inhibition of chondrogenesis in the distal limb as a result of elevated CatnB.

Progressing through to hypertrophy canonical Wnt signaling via CatnB has then to be up-regulated again. For example, in the developing chick limb, constitutively active CatnB promotes chondrocyte hypertrophy [150] whereas forced expression of Wnt5a will delay chondrocyte maturation to hypertrophic stages [75].

In spite of existing evidence with regard to stage specific regulation of chondrogenesis by canonical or non-canonical signaling, it is believed that the noncanonical pathway is essential for chondrogenesis as the canonical pathway is essential for osteogenesis [151]. Besides, the inactivation of CatnB will cause chondrocyte formation in an osteoinducing medium, thus reinforcing the idea that $\mathrm{CatnB}$ regulation is key to determining the fate of an osteo-chondro precursor [148]. Further evidence shows that the up-regulation of CatnB precedes osteoblast differentiation during intramembraneous ossification, whereas CatnB is down-regulated in the chondrogenic condensations and up-regulated in the surrounding cells during endochondral bone formation.

In conclusion, the canonical pathway inhibits progression of chondrocyte differentiation, enhances endochondral bone formation and promotes chondrocyte maturation similar to what is seen during ESC differentiation, where canonical signaling is required during early differentiation and late-stage chondrogenesis.

\section{Osteogenesis}

As we have presented, it seems likely that discrepancies in CatnB actions during chondrogenic differentiation simply reflect the stage-and dose-dependent requirement for canonical signaling. In osteogenesis, many Wnt pathway molecules show contradictory phenotypes depending on dose, time of treatment, cell line, and model organism.

The function of CatnB during in vivo bone development was shown by Hill et al. [152] with the deletion of CatnB in the mesenchyme using a Prx-Cre system. Here, CatnB was deleted in the forelimb and hindlimb mesenchyme starting with E10.5. The resulting phenotype of the $\mathrm{CatnB}^{\triangle \mathrm{PRX} /-}$ mutation resulted in arrest of early osteoblast differentiation and repression of mineralization leading to a truncation in the limbs. The cause of this phenotype was the down-regulated expression of osterix and complete loss of osteocalcin expression. Interestingly, a gain-of-function mutant generated by the same group showed a similar phenotype. 
Although these in vivo studies suggest that CatnB plays a role in osteogenesis, this role may vary in vitro depending on the cell line, stage of differentiation, and amount of CatnB protein present. Canonical Wnt signaling is thought to support osteogenic differentiation from both precursor lines and stem cell lines in vitro [153]. However, the exact effect of the canonical pathway on osteoblast formation is very stage-specific. Logan and Nüsse [64] suggested that CatnB blocks the differentiation of mesenchymal cells into skeletal precursors. By artificially increasing CatnB levels within the cell using lithium chloride treatment, ALP expression in the multipotent cell line C3H10T1/2 can be induced, but not sufficiently to induce osteocalcin expression. However, CatnB does increase osteocalcin promoter activity in MC3T3 cells, which is a more committed osteoblast cell line [132].

Canonical signaling seems to positively and negatively regulate the action of Runx2 on certain osteoblast specific promoters. In a gain-of-function study, CatnB enhanced LEF1-mediated repression of Runx2. Furthermore, LEF1 as well as TCF1 and TCF4 repressed Runx 2 activity on the osteocalcin promoter $[132,154]$. LEF1 has been shown to delay osteoblast differentiation in MC3T3 pre-osteoblast cells and regulate the expression of extracellular matrix proteins [155]. However, in different cellular contexts, Runx2 and LEF1/TCF cooperate to activate gene expression $[156,157]$.

It has been suggested that the stage of differentiation may be important in understanding the effect of the canonical pathway on osteogenesis. In ESCs, nuclear CatnB activity needs to be blocked in order for the cells to transgress from a mesodermal progenitor to a more committed osteoprogenitor (Fig. 2) [90]. The concept that canonical signaling is then suppressed in mature osteoblasts at later stages of differentiation [158] is supported by the increase in Dickkopf 1 and other Wnt antagonists in mature osteoblasts [159]. Moreover, CatnB is expressed in osteoblasts and not in osteocytes [160]. We can only speculate that the difference in CatnB effects might be attributed to the differentiation stages that these different model systems represent. Rodda and McMahon [161] also suggested that commitment within the osteoblast lineage requires sequential, stage-specific canonical signaling to promote osteogenesis and block chondrogenic programs of cell fate specification. Here, the conditional deletion of CatnB in early osteoblast progenitors and $\mathrm{Run} \times 2^{+} \mathrm{Osx}^{+}$precursors resulted in the osteoblasts failing to mature, characterized by decreased osteocalcin expression. Instead these immature osteoblast progenitors were converted into chondrocytes. In conclusion, progression of differentiation through to mature osteoblasts is dependent on fluctuations in nuclear CatnB activity achieved through a switch between canonical and non-canonical Wnt signaling.

\section{Conclusion}

Lineage specification of mesenchymal progenitors, either adult stem cells or ESC-derived, seems to be CatnB dependent and independent as CatnB seems to regulate only a subset of all genes required for proper and terminal differentiation. The described effects in the three lineages under discussion in this review may appear controversial at first sight, but clearly indicate that Wnt signaling must be tightly controlled in vivo and in vitro in all lineages to regulate proliferation and differentiation and thus the development of tissues. Specifically, it seems to be a switch between canonical and non-canonical Wnt signaling that depending on the time of differentiation it occurs at directs the cell into different fates. However, if these switches occur in the specification of all lineages, then what is it that specifies a chondrocyte rather than an osteoblast? Here, it will be critical to identify the regulators that turn the switch on or off at specific times of the differentiation path.

With increasing knowledge of pathways involved in fate decisions it becomes clear that directing differentiation with growth factors in vitro has to closely resemble the program that is initiated in vivo. Cell culture media and the timing of their application are becoming increasingly complex. In return, delineating the pathways that govern stem cell differentiation in vitro could ultimately help us understand how adipogenic tissue, bone and cartilage are generated in vivo.

Open Access This article is distributed under the terms of the Creative Commons Attribution Noncommercial License which permits any noncommercial use, distribution, and reproduction in any medium, provided the orginal author(s) and source are credited.

1 Amit, M., Carpenter, M. K., Inokuma, M. S., Chiu, C. P., Harris, C. P., Waknitz, M. A., Itskovitz-Eldor, J. and Thomson, J. A. (2002) Clonally derived human embryonic stem cell lines maintain pluripotency and proliferative potential for prolonged periods of culture. Dev. Biol. 227, 271-278.

2 Rattan, S. I. S. (2003) Aging outside the body: usefulness of the Hayflick system. In Aging of cells in and outside the body SC Kaul et al., eds (Kuwer Academic, London), pp 1-8

3 Stenderup, K., Justesen, J., Clausen, C. and Kassem, M. (2003) Aging is associated with decreased maximal life span and accelerated senescence of bone marrow stromal cells. Bone 33, 919-926.

4 Evans, M. J. and Kaufman, M. H. (1981) Establishment in culture of pluripotential cells from mouse embryos. Nature 292, 154-156.

5 Martin, G. R. (1981) Isolation of a pluripotent cell line from early mouse embryos cultured in medium conditioned by 
teratocarcinoma stem cells. Proc. Natl. Acad. Sci. USA 78, $7634-7638$.

6 Sato, N., Sanjuan, I. M., Heke, M., Uchida, M., Naef, F. and Brivanlou, A. H. (2003) Molecular signature of human embryonic stem cells and its comparison with the mouse. Dev. Biol. 260, 404-413.

7 Guasch, G. and Fuchs, E. (2005) Mice in the world of stem cell biology. Nat. Genet. 37, 1201-1206.

8 Smith, A. G. (2001) Embryo-derived stem cells: of mice and men. Annu. Rev. Cell. Dev. Biol. 17, 435-462.

9 Metcalf, D. (1990) The induction and inhibition of differentiation in normal and leukaemic cells. Philos. Trans. R. Soc. Lond. B. Biol. Sci. 327, 99-109.

10 Nichols, J., Davidson, D., Taga, T., Yoshida, K., Chambers, I and Smith, A. (1996) Complementary tissue-specific expression of LIF and LIF-receptor mRNAs in early mouse embryogenesis. Mech. Dev. 57, 123-131.

11 Tighe, A. P. and Gudas, L. J. (2004) Retinoic acid inhibits leukemia inhibitory factor signaling pathways in mouse embryonic stem cells. J. Cell. Physiol. 198, 223-229.

12 Kunath, T., Saba-El-Leil, M. K., Almousailleakh, M., Wray, J., Meloche, S. and Smith, A. (2007) FGF stimulation of the Erk1/2 signalling cascade triggers transition of pluripotent embryonic stem cells from self-renewal to lineage commitment. Development 134(16), 2895-2902.

13 Thomson, J. A., Itskovitz-Eldor, J., Shapiro, S. S., Waknitz, M. A., Swiergiel, J. J., Marshall, V. S. and Jones, J. M. (1998) Embryonic stem cell lines derived from human blastocysts. Science 282, 1145-1147

14 Xiao, L., Yuan, X. and Sharkis, S. J. (2006) Activin A maintains self-renewal and regulates fibroblast growth factor, Wnt, and bone morphogenic protein pathways in human embryonic stem cells. Stem Cells 24, 1476-1486.

15 Ying, Q. L., Nichols, J., Chamber, I. and Smith, A. (2003) BMP induction of Id proteins suppresses differentiation and sustains embryonic stem cell self-renewal in collaboration with STAT3. Cell 115, 281-292.

16 Vallier, L., Alexander, M. and Pedersen, R. A. (2005) Activin/ Nodal and FGF pathways cooperate to maintain pluripotency of human embryonic stem cells. J. Cell Sci. 118, 4495-4509.

17 Ogawa, K., Nishinakamura, R., Iwamatsu, Y., Shimosato, D. and Niwa, H. (2006) Synergistic action of Wnt and LIF in maintaining pluripotency of mouse ES cells. Biochem. Biophys. Res. Commun. 343, 159-166.

18 Verfaillie, C. M., Pera, M. F. and Lansdorp, P. M. (2002) Stem cells: hype and reality. Hematology Am. Soc. Hematol. Educ. Program., 369-391

19 Nichols, J., Zevnik, B., Anastassiadis, K., Niwa, H., KleweNebenius, D., Chambers, I., Scholer, H. and Smith, A. (1998) Formation of pluripotent stem cells in the mammalian embryo depends on the POU transcription factor Oct4. Cell 95, 379391.

20 Chambers, I., Colby, D., Robertson, M., Nichols, J., Lee, S. Tweedie, S. and Smith, A. (2003) Functional expression cloning of Nanog, a pluripotency sustaining factor in embryonic stem cells. Cell 113, 643-655.

21 Avilion, A. A., Nicolis, S. K., Pevny, L. H., Perez, L., Vivian, N. and Lovell-Badge, R. (2003) Multipotent cell lineages in early mouse development depend on SOX2 function. Genes. Dev. 17, 126-140.

22 Rogers, M. B., Hosler, B. A. and Gudas, L. J. (1991) Specific expression of a retinoic acid-regulated, zinc-finger gene, Rex1 , in preimplantation embryos, trophoblast and spermatocytes. Development 113, 815-824.

23 Boyer, L. A., Lee, T. I., Cole, M. F., Johnstone, S. E., Levine, S. S., Zucker, J. P., Guenter, M. G., Kumar, R. M., Murray, H. L., Jenner, R. G., Gifford, D. K., Melton, D. A., Jaenisch, R. and Young, R. A. (2005) Core transcriptional regulatory circuitry in human embryonic stem cells. Cell 122(6), 947956.

24 Loh, Y. H., Wu, Q., Chew, J. L., Vega, V. B., Zhang, W., Chen, X., Bourque, G., George, J., Leong, B., Liu, J., Wong, K. Y.,
Sung, K. W., Lee, C. W., Zhao, X. D., Chiu, K. P., Lipovich, L., Kuznetsov. V. A., Robson. P., Stanton. L. W., Wei. C. L., Ruan. Y., Lim. B. and Ng. H. H. (2006) The Oct4 and Nanog transcription network regulates pluripotency in mouse embryonic stem cells. Nat. Genet. 38(4), 431-440.

25 Boyer, L. A., Plath, K., Zeitlinger, J., Brambrink, T., Medeiros, L. A., Lee, T. I., Levine, S. S., Wernig, M., Tajonar, A., Ray, M. K., Bell, G. W., Otte, A. P., Vidal, M., Gifford, D. K., Young, R. A. and Jaenisch, R. (2006). Polycomb complexes repress developmental regulators in murine embryonic stem cells. Nature 441(7091), 349-353.

26 Wernig, M., Meissner, A., Foreman, R., Brambrink, T., Ku, M., Hochedlinger, K., Bernstein, B. E. and Jaenisch, R. (2007) In vitro reprogramming of fibroblasts into a pluripotent EScell-like state. Nature 448(7151), 318-324.

27 Okita, K., Ichisaka, T. and Yamanaka, S. (2007) Generation of germline-competent induced pluripotent stem cells. Nature 448(7151), 313-317.

28 Caplan, A. I. (1991) Mesenchymal stem cells. J. Orthop. Res. $9,641-650$

29 Johnstone, B., Hering, T. M. and Caplan, A. I. (1998) In vitro chondrogenesis of bone-marrow-derived mesenchymal progenitor cells. Exp. Cell. Res. 238, 265-272.

30 Di Rocco, G., Iachininoto, M. G., Tritarelli, A., Straino, S., Zacheo, A., Germani, A., Crea, F. and Capogrossi, M. C. (2006) Myogenic potential of adipose-tissue-derived cells. J. Cell Sci. 119, 2945-2952.

31 Wislet-Gendebien, S., Hans, G., Leprince, P., Rigo, J. M., Moonen, G. and Rogister, B. (2005) Plasticity of cultured mesenchymal stem cells: switch from nestin-positive to excitable neuron-like phenotype. Stem Cells 23, 392-402.

32 Hou, L., Cao, H., Wang, D., Wei, G., Bai, C., Zhang, Y. and Pei, X. (2003) Induction of umbilical cord blood mesenchymal stem cells into neuron-like cells in vitro. Int. J. Hematol. 78, 256-261.

33 Lamoury, F. M., Croitoru-Lamoury, J. and Brew, B. J. (2006) Undifferentiated mouse mesenchymal stem cells spontaneously express neural and stem cell markers Oct-4 and Rex-1. Cytotherapy 8(3), 228-242.

34 Lee, O. K., Kuo, T. K., Chen, W. M., Lee, K. D., Hsieh, S. L. and Chen, T. H. (2004) Isolation of multipotent mesenchymal stem cells from umbilical cord blood. Blood 103,1669-1675.

35 De Ugarte, D. A., Alfonso, Z., Zuk, P. A., Elbarbary, A., Zhu, M., Ashjian, P., Benhaim, P., Hedrick, M. H. and Fraser, J. K. (2003) Differential expression of stem cell-mobilizationassociated molecules on multi-lineage cells from adipose tissue and bone marrow. Immunol. Lett. 89, 267-270.

36 Young, H. E., Mancini, M. L., Wright, R. P., Smith, J. C., Black, Jr. A. C., Reagan, C. R. and Lucas, P. A. (1995) Mesenchymal stem cells reside within the connective tissues of many organs. Dev. Dyn. 202, 137-144.

37 Shih, D. T., Lee, D. C., Chen, S. C., Tsai, R. Y., Huang, C. T., Tsai, C. C., Shen, E. Y. and Chiu, W. T. (2005) Isolation and characterization of neurogenic mesenchymal stem cells in human scalp tissue. Stem Cells 23, 1012-1020.

38 Waller, E., Olweus, J., Lund-Johansen, F., Huang, S., Nguyen, M., Guo, G. and Terstappen, L. (1995) The "common stem cell" hypothesis reevaluated: human fetal bone marrow contains separate populations of hematopoetic and stromal progenitors. Blood 85, 2422-2435.

39 Friedenstein, A. J., Chailakhjan, R. K. and Lalykina, K. S. (1970) The development of fibroblast colonies in monolayer cultures of guinea-pig bone marrow and spleen cells. Cell. Tissue Kinet. 3, 393-403.

40 Dominici, M., Le Blanc, K., Mueller, I., Slaper-Cortenbach, I., Marini, F. C., Krause, D. S., Deans, R. J., Keating, A., Prockop, D. J. and Horwitz, E. M. (2006). Minimum criteria for defining multipotent mesenchymal stromal cells. The international society for cellular therapy position. Cytotherapy, 8(4), 315-317.

41 Stenderup, K., Justesen, J., Eriksen, E. F., Rattan, S. I. and Kassem, M. (2001) Number and proliferative capacity of 
osteogenic stem cells are maintained during aging and in patients with osteoporosis. J. Bone Miner. Res. 16, 1120-1129

42 Jones, E. A., English, A., Henshaw, K., Kinsey, S. E., Markham, A. F., Emery, P. and McGonagle, D. (2004) Enumeration and phenotypic characterization of synovial fluid multipotential mesenchymal progenitor cells in inflammatory and degenerative arthritis. Arthritis Rheum. 50, 817-827.

43 Pittenger, M. F., Mackay, A. M., Beck, S. C., Jaiswal, R. K. Douglas, R., Mosca, J. D., Moorman, M. A., Simonetti, D. W., Craig, S. and Marshak, D. R. (1999) Multilineage potential of adult human mesenchymal stem cells. Science 284, $143-147$.

44 Reyes, M., Lund, T., Lenvik, T., Aguiar, D., Koodie, L. and Verfaillie, C. M. (2001) Purification and ex vivo expansion of postnatal human marrow mesodermal progenitor cells. Blood 98, 2615-2625.

45 Jones, E. A., Kinsey, S. E., English, A., Jones, R. A., Straszynski, L., Meredith, D. M., Markham, A. F., Jack, A., Emery, P. and McGonagle, D. (2002) Isolation and characterization of bone marrow multipotential mesenchymal progenitor cells. Arthritis Rheum. 46, 3349-3360.

46 Quirici, N., Soligo, D., Bossolasco, P., Servida, F., Lumini, C. and Deliliers, G. L. (2002) Isolation of bone marrow mesenchymal stem cells by anti-nerve growth factor receptor antibodies. Exp. Hematol. 30, 783-791.

47 Cormier, J., zur Nieden, N. I., Rancourt, D. E. and Kallos, M. S. (2006) Short-term expansion of murine embryonic stem cells as aggregates in suspension culture bioreactors. Tissue Eng. 12(11), 3233-3245.

48 Draper, J. S., Moore, H. D., Ruban, L. N., Gokhale, P. J. and Andrews, P. W. (2004) Culture and characterization of human embryonic stem cells. Stem Cells Dev. 13, 325-336.

49 Moon, R. T., Bowerman, B., Boutros, M. and Perrimon, N. (2002) The promise and perils of Wnt signaling through betacatenin. Science 296, 1644-1646.

50 Miller, J. R., Hocking, A. M., Brown, J. D. and Moon, R. T. (1999) Mechanism and function of signal transduction by the $\mathrm{Wnt} /$ beta-catenin and $\mathrm{Wnt} / \mathrm{Ca} 2+$ pathways. Oncogene 18 , $7860-7872$.

51 Huelsken, J. and Behrens, J. (2002) The Wnt signalling pathway. J. Cell Sci. 115, 3977-3978.

52 Alonso, L. and Fuchs, E. (2003) Stem cells in the skin: waste not, Wnt not. Genes. Dev. 17, 1189-1200.

53 Staal, F. J. and Clevers, H. C. (2003) Wnt signaling in the thymus. Curr. Opin. Immunol. 15, 204-208.

54 Nüsse, R. (2005) Wnt signaling in disease and in development Cell Res. 15(1), 28-32.

55 Nelson, W. J. and Nusse, R. (1997) Convergence of Wnt, $\beta$ catenin, and cadherin pathways. Science 303, 1483-1487.

56 Bhanot, P., Brink, M., Samos, C. H., Hsieh, J. C., Wang, Y. Macke, J. P., Andrew, D., Nathans, J. and Nusse, R. (1996) A new member of the frizzled family from Drosophila functions as a Wingless receptor. Nature 382, 225-230.

57 Tamai, K., Semenov, M., Kato, Y., Spokony, R., Liu, C., Katsuyama, Y., Hess, F., Saint-Jeannet, J. P. and He, X. (2000) LDL-receptor-related proteins in Wnt signal transduction. Nature 407, 530-535.

58 Wehrli, M., Dougan, S. T., Caldwell, K., O'Keefe, L., Schwartz, S., Vaizel-Ohayon, D., Schejter, E., Tomlinson, A and DiNardo, S. (2000) arrow encodes an LDL-receptorrelated protein essential for Wingless signalling. Nature 407, 527-530.

59 Pfeifer, M. and Polakis, P. (2000) Wnt signaling in oncogenesis and embryogenesis - a look outside the nucleus. Science 287, $1606-1609$

60 Thomas, G. M., Frame, S., Goedert, M., Nathke, I., Polakis, P. and Cohen, P. (1999) A GSK3-binding peptide from FRAT1 selectively inhibits the GSK3-catalysed phosphorylation of axin and beta-catenin. FEBS Lett. 458(2), 247-251.

61 Umbhauer, M., Djiane A., Goisset, C., Penzo-Medez, A. Riou, J. F., Boucaut, J. C. and Shi, D. L. (2000) The C-terminal cytoplasmic Lys-thr-X-X-X-Trp motif in frizzled receptors mediates Wnt/beta-catenin signaling. Embo J 19(18), 49444954

62 Li, L., Yuan, H., Weaver, C. D., Mao, J., Farr, G. H. 3rd, Sussman, D. J., Jonkers, J., Kimelman, D. and Wu, D. (1999) Axin and Frat1 interact with Dvl and GSK, bridging Dvl to GSK in Wnt-mediated regulation of LEF-1. EMBO J. 18(15), $4233-4240$.

63 Smalley, M. J., Sara, E., Paterson, H., Naylor, S., Cook, D., Jayatilake, H., Fryer, L. G., Hutchinson, L., Fry, M. J. and Dale, T. C. (1999) Interaction of axin and Dvl-2 proteins regulates Dvl-2-stimulated TCF-dependent transcription. EMBO J. 18(10), 2823-2835.

64 Logan, C. Y. and Nusse, R. (2004) The Wnt signaling pathway in development and disease. Annu. Rev. Cell. Dev. Biol. 20, $781-810$.

65 Bienz, M. and Clevers, H. (2003) Armadillo/beta-catenin signals in the nucleus-proof beyond a reasonable doubt? Nat Cell Biol 5, 179-182.

66 Topol, L., Jiang, X., Choi, H., Garrett-Beal, L., Carolan, P. J. and Yang, Y (2003). Wnt-5a inhibits the canonical Wnt pathway by promoting GSK-3-independent beta-catenin degradation. J Cell Biol. 162(5), 899-908.

67 Shtutman, M., Zhurinsky, J., Simcha, I., Albanese, C., D'Amico, M., Pestell, R. and Ben-Ze'ev, A. (1999) The cyclin D1 gene is a target of the beta-catenin/LEF-1 pathway. Proc Natl Acd Sci USA 96, 5522-5527.

68 Eklof Spink, K., Fridman, S. G. and Weis, W. I. (2001). Molecular mechanisms of beta-catenin recognition by adenomatous polyposis coli revealed by the structure of an APC-beta-catenin complex. EMBO J 20(22), 6203-6212.

69 Ishitani, T., Kishida, S., Hyodo-Miura, J., Ueno, N., Yasuda, J., Waterman, M., Shibuya, H., Moon, R. T., Ninomiya-Tsuji, J. and Matsumoto, K. (2003) The TAK1-NLK mitogenactivated protein kinase cascade functions in the Wnt-5a/ $\mathrm{Ca}(2+)$ pathway to antagonize Wnt/beta-catenin signaling. Mol. Cell. Biol. 23, 131-139.

70 Topczewski, J., Sepich, D. S., Myers, D. C., Walker, C., Amores, A., Lele, Z., Hammerschmidt, M., Postlethwait, J. and Solnica-Krezel, L. (2001) The zebrafish glypican knypek controls cell polarity during gastrulation movements of convergent extension. Dev. Cell 1, 251-264.

71 Axelrod, J. D., Miller, J. R., Shulman, J. M., Moon, R. T. and Perrimon, N. (1998) Differential recruitment of Dishevelled provides signaling specificity in the planar cell polarity and Wingless signaling pathways. Genes Dev. 12, 2610-2622.

72 Boutros, M., Paricio, N., Strutt, D. I. and Mlodzik, M. (1998) Dishevelled activates JNK and discriminates between JNK pathways in planar polarity and wingless signaling. Cell 94, 109-118.

73 Wallingford, J. B., Rowning, B. A., Vogeli, K. M., Rothbacher, U., Fraser, S. E. and Harland, R. M. (2000) Dishevelled controls cell polarity during Xenopus gastrulation. Nature 405, 81-85.

74 Kuhl, M., Sheldahl, L. C., Park, M., Miller, J. R. and Moon, R. T. (2000) The Wnt/Ca2+ pathway: a new vertebrate Wnt signaling pathway takes shape. Trends Genet. 16, 279-283.

75 Yang, Y., Topol, L., Lee, H. and Wu, J. (2003) Wnt5a and Wnt5b exhibit distinct activities in coordinating chondrocyte proliferation and differentiation. Development 130, 10031015.

76 Haegele, L., Ingold, B., Naumann, H., Tabatabai, G., Ledermann, B. and Brandner, S. (2003) Wnt signaling inhibits neural differentiation of embryonic stem cells by controlling bone morphogenetic protein expression. Mol. Cell. Neurosci. 24, 696-708.

77 Aubert, J., Dunstan, H., Chambers, I. and Smith, A. (2002) Functional gene screening in embryonic stem cells implicates wnt antagonism in neural differentiation. Nat. Biotechnol. 20, $1240-1245$.

78 Lin, T., Chao, C., Saito, S., Mazur, S. J., Murphy, M. E., Appella, E. and Xu, Y. (2005) p53 induces differentiation of 
mouse embryonic stem cells by suppressing Nanog expression. Nat. Cell. Biol. 7(2), 165-171

79 Sato, N., Meijer, L., Skaltsounis, L., Greengard, P. and Brivanlou, A. H. (2004) Maintenance of pluripotency in human and mouse embryonic stem cells through activation of wnt signaling by a pharmacological GSK-3-specific inhibitor. Nat. Med. 10, 55-63

80 Hay, N. and Sonenberg, N. (2004). Upstream and downstream of mTOR. Genes Dev. 18(16), 1926-1945.

81 Kielman, M. F., Rindapaa, M., Gaspar, C., van Poppel, N., Breukel, C., van Leeuwen, S., Taketo, M. M., Roberts, S. Smits, R. and Fodde, R. (2002) Apc modulates embryonic stem-cell differentiation by controlling the dosage of $\beta$-catenin signaling. Nat. Genet. 32, 594-605.

82 Miyabayashi, T., Teo, J. L., Yamamoto, M., McMillan, M. Nguyen, C. and Kahn, M. (2007). Wnt/beta-catenin/CBP signaling maintains long-term murine embryonic stem cell pluripotency. Proc. Natl. Acad. Sci. USA. 104(13), 5668 5673.

83 Sommer, L. and Rao, M. (2002) Neural stem cells and regulation of cell number. Prog. Neurobiol. 66, 1-18

84 Tosh, D. and Slack, J. M. (2002) How cells change their phenotype. Nat. Rev. Mol. Cell. Biol. 3, 187-194

85 Ross, S. E., Hemati, N., Longo, K. A., Bennett, C. N., Lucas, P. C., Erickson, R. L. and MacDougald, O. A. (2000) Inhibition of adipogenesis by wnt signaling. Science $289,950-953$

86 McBeath, R., Pirone, D. M., Nelson, C. M., Bhadriraju, K. and Chen, C. S. (2004) Cell shape, cytoskeletal tension and RhoA regulate stem cell lineage commitment. Am. J. Physiol. 275, R 1898-1908.

87 Tuan, R. S. (2003) Cellular signaling in developmental chondrogenesis: N-cadherin, Wnts, and BMP-2. J. Bone Joint Surg. Am. 85-A Suppl 2, 137-141

88 Dani, C., Smith, A. G., Dessolin, S., Leroy, P., Staccini, L., Villageois, P., Darimont, C. and Ailhaud, G. (1997) Differentiation of embryonic stem cells into adipocytes in vitro. $\mathrm{J}$ Cell Sci. 110, 1279-1285.

89 Kramer, J., Hegert, C., Guan, K., Wobus, A. M., Muller, P. K and Rohwedel, J. (2000) Embryonic stem cell-derived chondrogenic differentiation in vitro: activation by BMP-2 and BMP-4. Mech. Dev. 92, 193-205.

90 Phillips, B. W., Belmonte, N., Vernochet, C., Ailhaud, G. and Dani, C. (2001) Compactin enhances osteogenesis in murine embryonic stem cells. Biochem. Biophys. Res. Commun. 284, 478-484.

91 Buttery, L. D., Bourne, S., Xynos, J. D., Wood, H., Hughes, F. J., Hughes, S. P., Episkopou, V. and Polak, J. M. (2001) Differentiation of osteoblasts and in vitro bone formation from murine embryonic stem cells. Tissue Eng. 7, 89-99.

92 zur Nieden, N. I., Kempka, G. and Ahr, H. J. (2003) In vitro differentiation of embryonic stem cells into mineralized osteoblasts. Differentiation 71, 18-27.

93 zur Nieden, N. I., Kempka, G. and Ahr, H. J. (2004) Molecular multiple endpoint embryonic stem cell test-a possible approach to test for the teratogenic potential of compounds. Toxicol. Appl. Pharmacol. 194, 257-269.

94 Leahy, A., Xiong, J. W., Kuhnert, F. and Stuhlmann, H. (1999) Use of developmental marker genes to define temporal and spatial patterns of differentiation during embryoid body formation. J. Exp. Zool. 284, 67-81.

95 Fehling, H. J., Lacaud, G., Kubo, A., Kennedy, M., Robertson, S., Keller, G. and Kouskoff, V. (2003) Tracking mesoderm induction and its specification to the hemangioblast during embryonic stem cell differentiation. Development 130, 42174227.

96 Orkin, S. H. and Pera, M. P. (2007). Stem cells down under ISSCR 2007. Cell Stem Cell 1, 271-276.

97 Christy, R. J., Yang, V. W., Ntambi, J. M., Geiman, D. E., Landschulz, W. H., Friedman, A. D., Nakabeppu, Y., Kelly, T. J. and Lane, M. D. (1989) Differentiation-induced gene expression in 3T3-L1 preadipocytes: CCAAT/enhancer bind- ing protein interacts with and activates the promoters of two adipocyte-specific genes. Genes. Dev. 3(9), 1323-1335.

98 Chawla, A., Schwarz, E. J., Dimaculangan, D. D. and Lazar, M. A. (1994) Peroxisome proliferator-activated receptor (PPAR) gamma: adipose-predominant expression and induction early in adipocyte differentiation. Endocrinology 135(2), 798-800.

99 Ducy, P., Zhang, R., Geoffroy, V., Ridall, A. L. and Karsenty, G. (1997) Osf2/Cbfa1: a transcriptional activator of osteoblast differentiation. Cell 89(5), 747-754.

100 Lee, M. H., Kwon, T. G., Park, H. S., Wozney, J. M. and Ryoo, H. M. (2003) BMP-2-induced Osterix expression is mediated by Dlx 5 but is independent of Runx 2 . Biochem. Biophys. Res. Commun. 309(3), 689-694.

101 Lefebvre, V., Huang, W., Harley, V. R., Goodfellow, P. N. and de Crombrugghe, B. (1997) SOX9 is a potent activator of the chondrocyte-specific enhancer of the pro alpha1(II) collagen gene. Mol. Cell. Biol. 17(4), 2336-2346.

102 Enomoto, H., Furuichi, T., Zanma, A., Yamana, K., Yoshida, C., Sumitani, S., Yamamoto, H., Enomoto-Iwamoto, M., Iwamoto, M. and Komori, T. (2004) Runx2 deficiency in chondrocytes causes adipogenic changes in vitro. J. Cell Sci. $117,417-425$

103 Lecka-Czernik, B., Gubril, I., Moerman, E. J., Kajkenova, O., Lipschitz, D. A., Manolagas, S. C. and Jilka, R. L. (1999) Inhibition of Osf2/Cbfa1 expression and terminal osteoblast differentiation by PPARgamma2. J. Cell. Biochem. 74, 357371.

104 zur Nieden, N. I., Kempka, G., Rancourt, D. E. and Ahr, H. J. (2005) Induction of chondro-, osteo- and adipogenesis in embryonic stem cells by bone morphogenetic protein-2: effect of cofactors on differentiating lineages. BMC Dev. Biol. 5, 1

105 Mulholland, D. J., Dedhar, S., Coetzee, G. A. and Nelson, C. C. (2005) Interaction of nuclear receptors with the Wnt/ beta-catenin/Tcf signaling axis: Wnt you like to know? Endocr. Rev. 26, 898-915.

106 Aranda, A. and Pascual, A. (2001) Nuclear hormone receptors and gene expression Physiol. Rev. 81, 1269-1304.

107 Francis, G. A., Fayard, E., Picard, F. and Auwerx, J. (2003) Nuclear receptors and the control of metabolism. Annu. Rev. Physiol. 65, 261-311.

108 Koutnikova, H. and Auwerx, J. (2001) Regulation of adipocyte differentiation. Ann. Med. 33, 556-561.

109 Otto, T. C. and Lane, M. D. (2005) Adipose development: from stem cell to adipocyte. Crit. Rev. Biochem. Mol. Biol. 40, 229-242.

110 Patel, Y. M. and Lane, M. D. (2000) Mitotic clonal expansion during preadipocyte differentiation: calpain-mediated turnover of p27. J. Biol. Chem. 275, 17653-17660.

111 Tang, Q. Q., Otto, T. C. and Lane, M. D. (2003) CCAAT/ Enhancer-binding protein beta is required for mitotic clonal expansion during adipogenesis. Proc. Natl. Acad. Sci. USA $100,850-855$.

112 Christy, R. J., Kaestner, K. H., Geiman, D. E. and Lane, M. D. (1991) CCAAT/enhancer binding protein gene promoter: binding of nuclear factors during differentiation of 3T3-L1 preadipocytes. Proc. Natl. Acad. Sci. USA 88, 2593-2597.

113 Tontonoz, P., Hu, E., Graves, R. A., Budavari, A. I. and Spiegelman, B. M. (1994) mPPAR $\gamma 2$ : tissue-specific regulator of an adipocyte enhancer. Genes Dev. 8, 1224-1234.

114 Kliewer, S. A., Lenhard, J. M., Willson, T. M., Patel, I., Morris, D. C. and Lehmann, J. M. (1995) A prostaglandin J2 metabolite binds peroxisome proliferator-activated receptor gamma and promotes adipocyte differentiation. Cell 83, 813819.

115 Forman, B. M., Tontonoz, P., Chen, J., Brun, R. P., Spiegelman, B. M. and Evans, R. M. (1995) 15-Deoxy-delta 12, 14prostaglandin $\mathrm{J} 2$ is a ligand for the adipocyte determination factor PPAR $\gamma$. Cell 83, 803-812.

116 zur Nieden, N. I., Price, F. D., Davis, L. A., Everitt, R. E. and Rancourt, D. E. (2007) Gene profiling on mixed ES cell 
populations reveals a biphasic role for beta-catenin in osteogenic differentiation. Mol. Endocrinol. 21(3), 674-685.

117 Kawaguchi, J., Mee, P. J. and Smith, A. G. (2005) osteogenic and chondrogenic differentiation of embryonic stem cells in response to specific growth factors. Bone 36, 758-769.

118 Billon, N., Iannarelli, P., Monteiro, M. C., Glavieux-Pardanaud, C., Richardson, W. D., Kessaris, N., Dani, C. and Dupin, E. (2007) The generation of adipocytes by the neural crest. Development 134(12), 2283-2292.

119 Xiong, C., Xie, Ch.-Q., Zhang, L., Zhang, J., Xu, K., Fu, M. Thompson, W. E., Yang, L.-Y. and Chen, Y. E. (2005) Derivation of adipocytes from human embryonic stem cells. Stem Cells Dev. 14, 671-675.

120 Benvenuti, S., Cellai, I., Luciani, P., Deledda, C., Baglioni, S., Giuliani, C., Saccardi, R., Mazzanti, B., Dal Pozzo, S., Mannucci, E., Peri, A., and Serio, M. (2007). Rosiglitazone stimulates adipogenesis and decreases osteoblastogenesis in human mesenchymal stem cells. J Endocrinol Invest. 30(9), RC26-30.

121 Siu, Y., Clarke, T. and Khillan, J. S. (2003) Limb bud progenitor cells induce differentiation of pluripotent embryonic stem cells into chondrogenic lineage. Differentiation 71, $578-585$.

122 Noël, D., Gazit, D., Bouquet, C., Apparailly, F., Bony, C., Plence, P., Millet, V., Turgeman, G., Perricaudet, M., Sany, J. and Jorgensen, C. (2004) Short-term BMP-2 expression is sufficient for in vivo osteochondral differentiation of mesenchymal stem cells. Stem Cells 22(1), 74-85.

123 Goessler, U. R., Bugert, P., Bieback, K., Deml, M., Sadick, H., Hormann, K. and Riedel, F. (2005) In-vitro analysis of the expression of TGFbeta -superfamily-members during chondrogenic differentiation of mesenchymal stem cells and chondrocytes during dedifferentiation in cell culture. Cell Mol. Biol. Lett. 10(2), 345-362.

124 Nakayama, N., Duryea, D., Manoukian, R., Chow, G. and Han, C. Y. (2003) Macroscopic cartilage formation with embryonic stem-cell-derived mesodermal progenitor cells. J. Cell Sci. 116(Pt 10), 2015-2028.

125 Kitamura, S., Ohgushi, H., Hirose, M., Funaoka, H., Takakura, Y. and Ito, H. (2004) Osteogenic differentiation of human bone marrow-derived mesenchymal cells cultured on alumina ceramics. Artif. Organs. 28(1), 72-82.

126 Sottile, V., Thomson, A. and McWhir, J. (2003) In vitro osteogenic differentiation of human ES cells. Cloning Stem Cells 5, 149-155.

127 Tai, G., Polak, J. M., Bishop, A. E., Christodoulou, I. and Buttery, L. D.K. (2004) Differentiation of osteoblasts from murine embryonic stem cells by overexpression of the transcriptional factor osterix. Tissue Eng. 10, 1456-1466.

128 Yamane, T., Kunisada, T., Yamazaki, H., Era, T., Nakano, T. and Hayashi, S. I. (1997) Development of osteoclasts from embryonic stem cells through a pathway that is c-fms but not c-kit dependent. Blood 90, 3516-3523.

129 Kieslinger, M., Folberth, S., Dobreva, G., Dorn, T., Croci, L., Erben, R., Consalez, G. G. and Grosschedl, R. (2005) EBF2 regulates osteoblast-dependent differentiation of osteoclasts. Dev. Cell 9, 757-767.

130 Labbe, E., Letamendia, A. and Attisano, L. (2000) Association of Smads with lymphoid enhancer binding factor $1 / \mathrm{T}$ cell-specific factor mediates cooperative signaling by the transforming growth factor-beta and wnt pathways. Proc. Natl. Acad. Sci. USA 97, 8358-8363.

131 Nishita, M., Hashimoto, M. K., Ogata, S., Laurent, M. N. Ueno, N., Shibuya, H. and Cho, K. W. (2000) Interaction between Wnt and TGF-beta signalling pathways during formation of Spemann's organizer. Nature 403, 781-785.

132 Kahler, R. A. and Westendorf, J. J. (2003) Lymphoid enhancer factor-1 and beta-catenin inhibit Runx2-dependent transcriptional activation of the osteocalcin promoter. J. Biol. Chem. 278, 11937-11944.
133 Michalik, L., Desvergne, B. and Wahli, W. (2004) Peroxisomeproliferator-activated receptors and cancers: complex stories. Nat. Rev. Cancer 4, 61-70.

134 He, T. C., Chan, T. A., Vogelstein, B. and Kinzler, K. W. (1999) PPARס is an APC-regulated target of non-steroidal anti-inflammatory drugs. Cell 99, 335-345.

135 Hansen, J. B., Zhang, H., Rasmussen, T. H., Petersen, R. K., Flindt, E. N. and Kristiansen (2001) Peroxisome proliferatoractivated receptor delta (PPARdelta)-mediated regulation of preadipocyte proliferation and gene expression is dependent cAMP signalling. J. Biol. Chem. 276, 3175-3182.

136 Fu, M., Rao, M., Bouras, T., Wang, C., Wu, K., Zhang, X., Li, Z., Yao, T. P. and Pestell, R. G. (2005) Cyclin D1 inhibits peroxisome proliferator-activated receptor gamma-mediated adipogenesis through histone deacetylase recruitment. J. Biol. Chem. 280, 16934-16941.

137 Tetsu, O. and McCormick, F. (1999) Beta-catenin regulates expression of cyclin D1 in colon carcinoma cells. Nature 398, $422-426$.

138 Moldes, M., Zuo, Y., Morrison, R. F., Silva, D., Park, B. H., Liu, J. and Farmer, S. R. (2003) Peroxisome-proliferatoractivated receptor gamma suppresses wnt-beta-catenin signalling during adipogenesis. Biochem. J. 376, 607-613

139 Bennett, C. N., Ross, S. E., Longo, K. A., Bajnok, L., Hemati, N., Johnson, K. W., Harrison, S. D. and MacDougald, O. A. (2002) Regulation of wnt signaling during adipogenesis. J. Biol. Chem. 277, 30998-31004.

140 Bennett, C. N., Longo, K. A., Wright, W. S., Suva, L. J., Lane, T. F., Hankenson, K. D. and MacDougald, O. A. (2005) Regulation of osteoblastogenesis and bone mass by Wnt10b. Proc. Natl. Acad. Sci. USA 102, 3324-3329.

141 Rawadi, G., Vayssiere, B., Dunn, F., Baron, R. and RomanRoman, S. (2003) BMP-2 controls alkaline phosphatase expression and osteoblast mineralization by a wnt autocrine loop. J. Bone Miner. Res. 18, 1842-1853.

142 MacDougald, O. A., Cornelius, P., Liu, R. and Lane, M. D. (1995) Insulin regulates transcription of the CCAAT/Enhancer binding protein (C/EBP) alpha, beta and delta genes in fully differentiated 3T3-L1 adipocytes. J. Biol. Chem. 270, 647-654.

143 Ross, S. E., Erickson, R. L., Hemati, N. and MacDougald, O. A. (1999) Glycogen synthase kinase 3 is an insulinregulated C/EBPalpha kinase. Mol. Cell. Biol. 19, 8433-8441.

144 Bandyopadhyay, G., Standaert, M., Sajan, M. P., Kanoh, Y., Miura, A., Barun, U., Kruse, F. and Leitges, M. (2004) Protein kinase $\mathrm{C}-1$ knockout in embryonic stem cells and adipocytes impairs insulin-stimulated glucose transport. Mol. Endocrinol. 18, 373-383.

145 Yang, X., Jansson, P.-A., Nagaev, I., Jack, M. M., Carvalho, E., Stibrant Sunnerhagen, K., Cam, M. C., Cushman, S. W. and Smith, U. (2004) Evidence of impaired adipogenesis in insulin resistance. Biochem. Biophys. Res. Com. 317, 10451051

146 Akiyama, H., Lyons, J. P., Mori-Akiyama, Y., Yang, X., Zhang, R., Zhang, Z., Deng, J. M., Taketo, M. M., Nakamura, T., Behringer, R. R., McCrea, P. D. and de Crombrugghe, B. (2004) Interactions between Sox 9 and beta-catenin control chondrocyte differentiation. Genes. Dev. 18, 1072-1087.

147 Ryu, J. H., Kim, S. J., Kim, S. H., Oh, C. D., Hwang, S. G., Chun, C. H., Oh, S. H., Seong, J. K., Huh, T. L. and Chun, J. S. (2002) Regulation of the chondrocyte phenotype by betacatenin. Development 129(23), 5541-5550.

148 Day, T. F., Guo, X., Garrett-Beal, L. and Yang, Y. (2005) Wnt/ beta-catenin signaling in mesenchymal progenitors controls osteoblast and chondrocyte differentiation during vertebrate skeletogenesis. Dev. Cell 8, 739-750.

149 Topol, L., Jiang, X., Choi, H., Garrett-Beal, L., Carolan, P. J. and Yang, Y. (2003) Wnt-5a inhibits the canonical Wnt pathway by promoting GSK-3-independent beta-catenin degradation. J. Cell. Biol. 162, 899-908. 
150 Hartmann, C. and Tabin, C. J. (2001) Wnt-14 plays a pivotal role in inducing synovial joint formation in the developing appendicular skeleton. Cell 104, 341-351.

151 Hu, H., Hilton, M. J., Tu, X., Yu, K., Ornitz, D. M. and Long, F. (2005) Sequential roles of Hedgehog and Wnt signaling in osteoblast development. Development 132, 49-60.

152 Hill, T. P., Spater, D., Taketo, M. M., Birchmeier, W. and Hartmann, C. (2005) Canonical Wnt/beta-catenin signaling prevents osteoblasts from differentiating into chondrocytes. Dev. Cell 8, 727-738.

153 Bain, G., Muller, T., Wang, X. and Papkoff, J. (2003) Activated beta-catenin induces osteoblast differentiation of C3H10T1/2 cells and participates in BMP2 mediated signal transduction. Biochem. Biophys. Res. Commun. 301, 84-91.

154 Westendorf, J. J., Kahler, R. A. and Schroeder, T. M. (2004) Wnt signaling in osteoblasts and bone disease. Gene 341, 1939.

155 Kahler, R. A., Galindo, M., Lian, J., Stein, G. S., van Wijnen, A. J. and Westendorf, J. J. (2006) Lymphocyte enhancerbinding factor 1 (Lef1) inhibits terminal differentiation of osteoblasts. J. Cell. Biochem. 97, 969-983.

156 Bruhn, L., Munnerlyn, A. and Grosschedl, R. (1997) ALY, a context-dependent coactivator of LEF-1 and AML-1, is required for TCRalpha enhancer function. Genes. Dev. 11, $640-653$.
157 El-Tanani, M., Fernig, D. G., Barraclough, R., Green, C. and Rudland, P. (2001) Differential modulation of transcriptional activity of estrogen receptors by direct protein-protein interactions with the $\mathrm{T}$ cell factor family of transcription factors. J. Biol. Chem. 276, 41675-41682.

158 Boland, G. M., Perkins, G., Hall, D. J. and Tuan, R. S. (2004) Wnt 3a promotes proliferation and suppresses osteogenic differentiation of adult human mesenchymal stem cells. J. Cell. Biochem. 93, 1210-1230.

159 Kalajzic, I., Staal, A., Yang, W. P., Wu, Y., Johnson, S. E., Feyen, J. H., Krueger, W., Maye, P., Yu, F., Zhao, Y., Kuo, L., Gupta, R. R., Achenie, L. E., Wang, H. W., Shin, D. G. and Rowe, D. W. (2005) Expression profile of osteoblast lineage at defined stages of differentiation. J. Biol. Chem. 280, 2461824626.

160 Monaghan, H., Bubb, V. J., Sirimujalin, R., Millward-Sadler, S. J. and Salter, D. M. (2001) Adenomatous polyposis coli (APC), beta-catenin, and cadherin are expressed in human bone and cartilage. Histopathology 39, 611-619.

161 Rodda, S. J. and McMahon, A. P. (2006) Distinct roles for Hedgehog and canonical Wnt signaling in specification, differentiation and maintenance of osteoblast progenitors. Development 133, 3231-3244.

\section{To access this journal online: http://www.birkhauser.ch/CMLS}

